\title{
CELTIC GOLD TORCS
}

\author{
Christiane Eluère \\ Musée des Antiquités Nationales, F-78103 Saint-Germain-en-Laye, France
}

\begin{abstract}
Torcs are a specific type of ornamented metal neckring, which are typical artefacts of ancient barbarians. This study of Celtic gold torcs introduces the use of modern technology to analyse and classify the finds. The results empliasise the dynamic character of goldworking practised in the late, pre-Roman Celtic times.
\end{abstract}

The etymology of the word 'torc' is from the latin word torques meaning 'twisted bar'; these neckrings indeed are often in the form of a twisted bar or rod, ending in protruding terminals which may be functional or decorative.

Celtic gold torcs are characteristic artefacts; hence their study provides information on changing trends and developments in both their use and in gold technology during Celtic pre-Roman times (5th to 1st century BC). Some of these torcs have been discovered in archaeological contexts (around a hundred sites have provided approximately 150 gold torcs in the Celtic area proper between Bohemia, southwestern France, the British Isles and in related cultural groups in the northwestern part of the Iberian peninsula).

In the Hellenistic world, from the end of the 4th century BC, such rigid neckrings seem very rare, while bracelets with a twisted hoop and terminals with lions', rams' or human heads are widespread. At this time, articulated and bead necklaces or chains were fashionable products of classical goldwork.

It has been reported by classical authors (i) that when the Celts, especially the Gauls, were fighting against Greeks or Romans, their chiefs were adorned with a gold torc during battle. Such reports also reveal that these torcs were often robbed from captured or dead Celtic warriors, and sometimes offered in the temples, or dedicated to the victorious leader. For example, the Romans under Cornelius, after their victory over the Boii (a Celtic tribe of central Europe), displayed their weapons, flags, captured horses and 1471 gold neckrings in front of the vanquished Celts. Gold torcs were sometimes used by the Romans too, particularly as rewards given to collaborating barbarians. But in his Gallic Wars, Caesar did not mention these collars, which may have fallen out of use by then. In Germanic countries, however, their use continued until late after the Roman conquest (2).

Pictures of Celts wearing torcs can be seen on some metal or stone monuments. The earliest ones are dated to the 3rd century BC, as, for example, the 'dying warrior' in a Hellenistic sculpture group from Pergamum (Figure 1). Also, indigenous figures of Celtic deities are represented with a torc around their neck or in their hand. On a large silver cauldron, for example, found in a marsh at Gundestrup (Denmark, 1st century BC), several figures of gods are adorned with torcs, especially that of Cernunnos (Figure 2), the god with deer horns.

Several local sculptures in Gaul, dated to around the birth of Christ, represent deities with torcs - a stone sculpture from Euffigneix (Haute-Marne, France) for example, or the bronze figure from Bouray (Essonne, France). Another group of indigenous figures comprising warriors' heads, or warriors in hieratic positions, sometimes with the statues deliberately beheaded or defaced, are found in sanctuaries in southern France, while others are known throughout Europe (Czechoslovakia and Spain).

Later, small bronze statues of the Gallo-Roman period (1st to 4th century AD) sometimes had a loop of twisted silver or gold wire added around the neck to simulate a torc. 


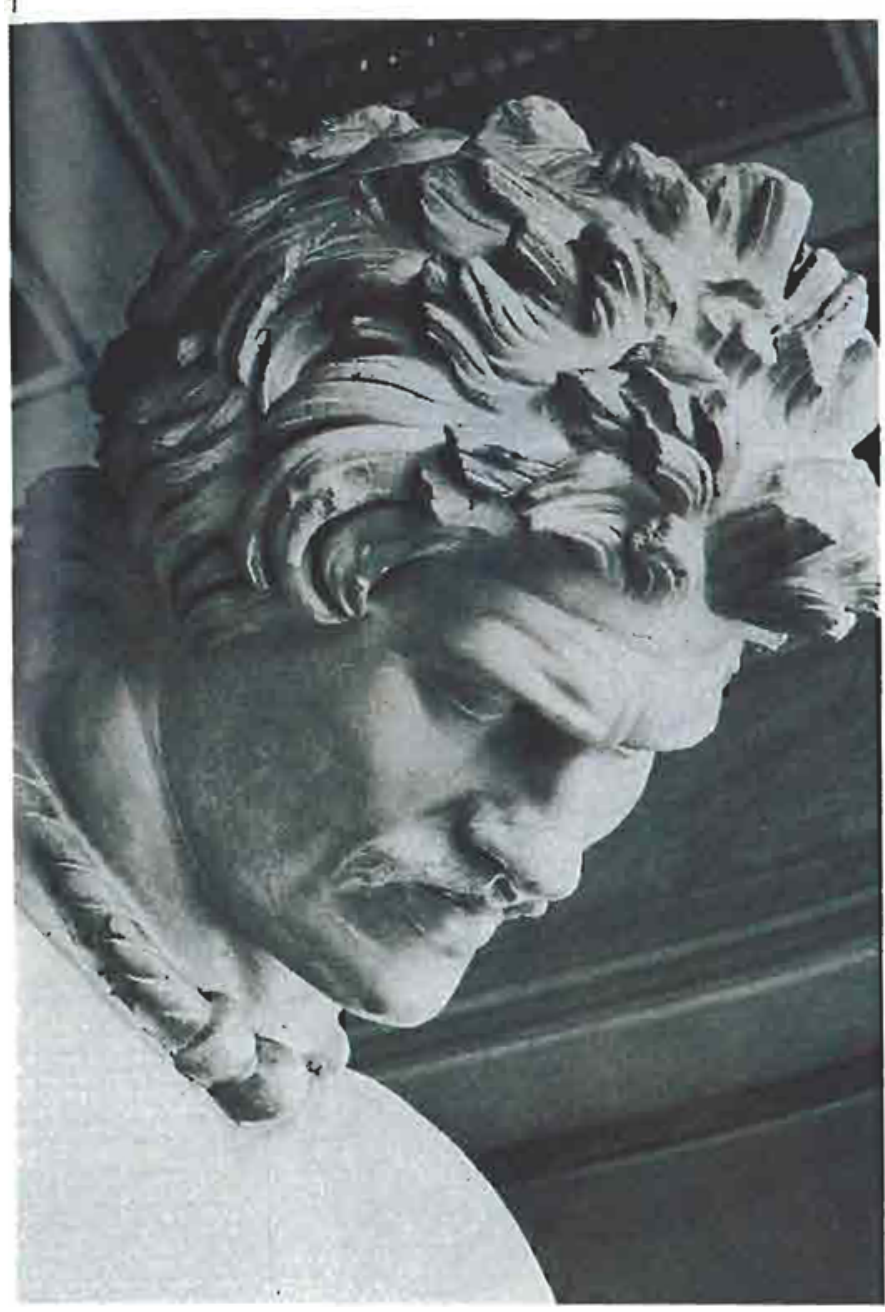

Fig. 1 'Dying Warrior'. Roman copy in stone of the original bronze figure in Pergamum (Asia Minor) dated 3rd century BC (note the torc adornment)

A Latin inscription in Riez (southern France) mentions a statue dedicated to Aesculapius which had to be adorned with a golden torc. Torcs are also symbols represented on several Celtic coins.

Hence, texts and iconographic documents sketch the important social and religious roles of tores in general. Obviously torcs made of gold must have been the most famous and precious. From archaeological data, we know that most of them appear later than the bronze ones, and therefore were probably contemporary to, or even the models of, those represented on monuments of the 3 rd to the 1 st century BC or later.

The role of gold torcs may possibly have been different to those of the bronze ones, the latter being very frequent during the 5th century $\mathrm{BC}$, and are obviously female ornaments (they are only found in women's burials, although

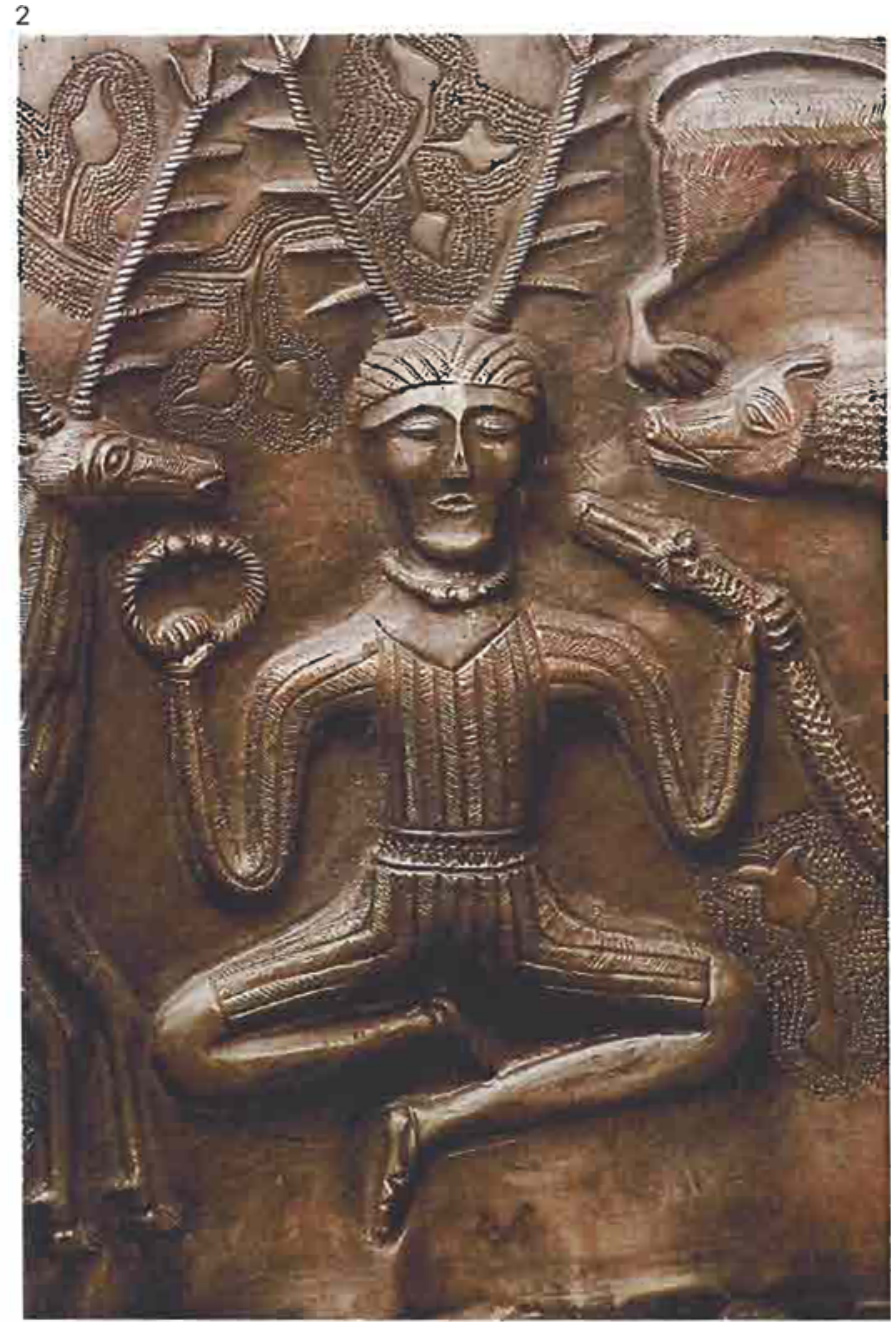

Fig. 2 The god Cermunnos wearing a torc. Detail of the silver cauldron from Gundestrup (Denmark). National Museum, Copenhagen gold examples also occur). A change is seen after the 4th century BC and the torcs henceforward seem to become warriors' or males' attributes, as attested by written descriptions or monuments. However, very few of these have been found in male burials, for they have been discovered mostly in hoards with other treasures, or singly, and are frequently made of gold.

The Celtic torcs (5th to 1st century BC) described in this paper may come from a very old tradition (3): indeed rigid neckrings in metal (gold, silver, copper, bronze) of various types have been produced from the beginning of the 2nd millenium BC (the beginning of the Bronze Age). The most ancient torcs in copper and bronze have been made by hammering a bar, and they often constitute hoards of several hundred pieces considered as ingots, particularly in central Europe. They are widespread in burials ranging 
3
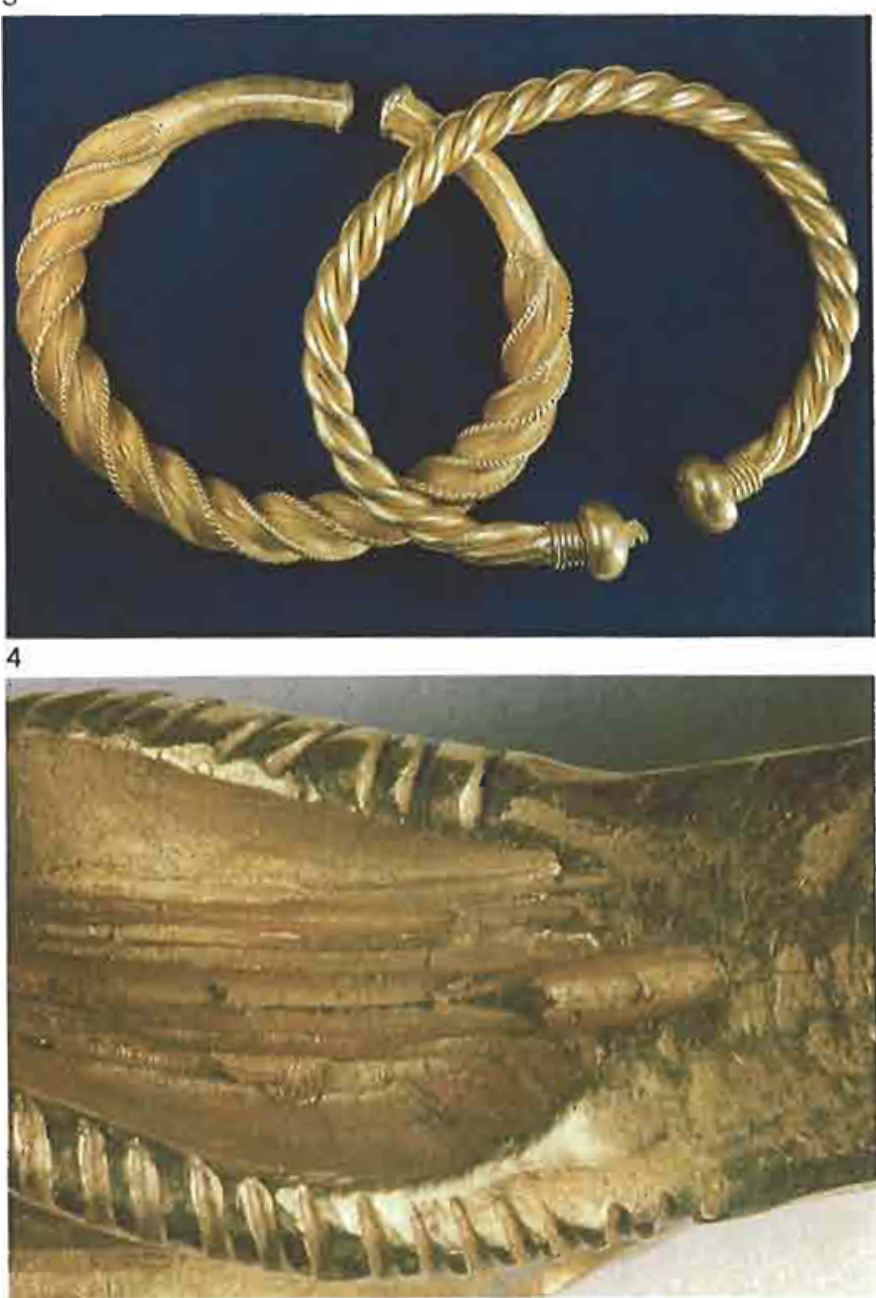

from the Middle East to eastern France.

Some rare gold torcs are known from the same period on the Atlantic coasts of Europe. From around 1500 to $800 \mathrm{BC}$, most torcs were made of bronze. The twisted pattern occurs often, and some groups are possible originators of the Celtic tradition. Flange, or strip-twisted, gold bar torcs (produced by hammering) around 1 metre long are typical products from Brittany and the British Isles around $1000 \mathrm{BC}$.

In northern Europe, heavy twisted bronze neckrings were frequent female offerings at the beginning of the Iron Age (6th to 4th century $\mathrm{BC}$ ). A twisted neckring is the attribute of some deities, as may be seen on the small bronze female figure with golden eyes found at Fardal (Denmark), for example. The twisted neckring has another relationship to Iron Age culture - that of the 'bog' people, whose wellpreserved remains have been found in peat soils. Some of these individuals have a twisted rope around the neck, although they were not killed by strangulation. This rope collar may be representative of a metallic twisted torc (4).
$5 a$

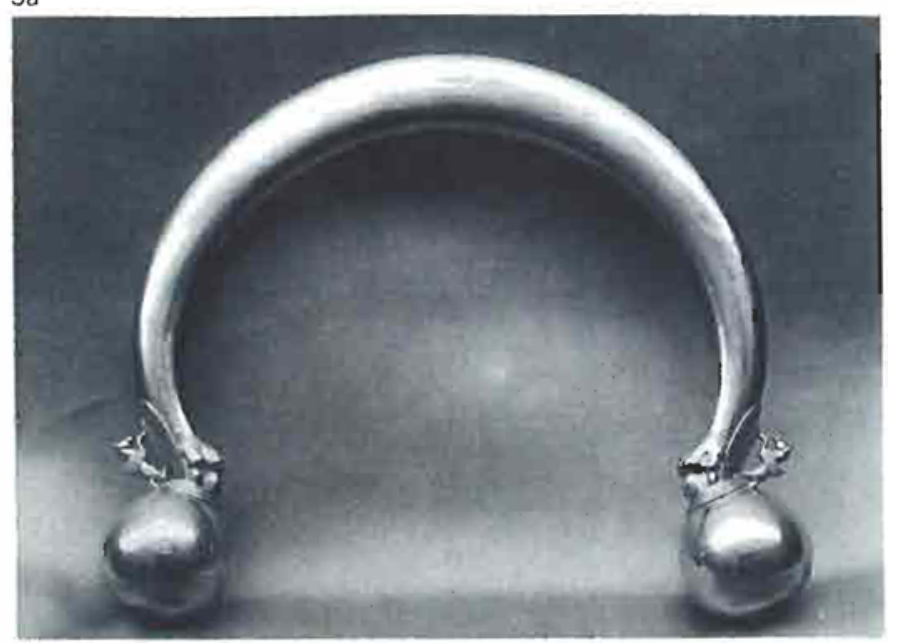

$5 b$

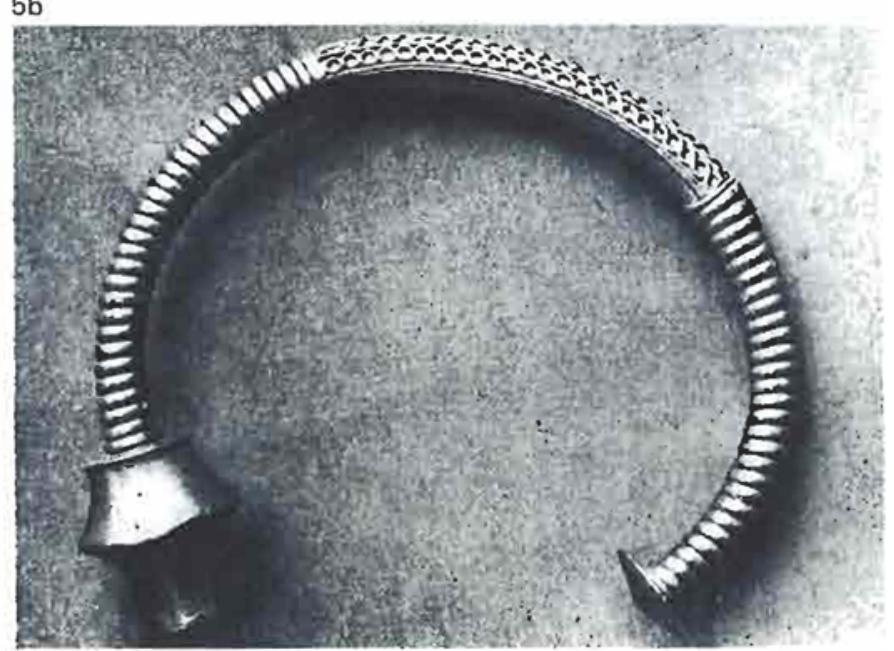

Fig. 3 Simple twisted torcs from the hoard at Soucy (Aisne, France), Note the simple terminals on the left-hand torc compared with the hook and slit clasp of the torc on the right. Musée de Cluny, Paris

Fig. 4 Detail of the hammering and chiselling used to give one of the simple torcs from Soucy its twisted appearance

Fig. 5 (a \& b) Tores with voluminous terminals. a). Gold jewel from the Vix burial (Côte-d’Or, France), Musée de Châtillon-sur.Seine; b). gold torc from Punta de Marzan (Lugo, Spain); one of the terminals is missing

On the monuments of Celtic times, torcs are always represented as circular rings (twisted or smooth), with their protruding ends tightly closed. This need for fastening the neckrings when worn seems to have required technical adjustments on the objects themselves. Since the terminals and clasp systems devised for this purpose reflect the technology of the time, they have been used here as a basis for classifying torcs. 
Terminals and Clasps: Types and Techniques Torcs without a Clasp

Torcs made from a simple, thin gold rod are sometimes found in the Iron Age, but are not really very typical, neither of a period nor of a country. Examples of these have been found in a burial at Maikop (South Russia, 5th century $\mathrm{BC}$ ) (5). In some burials, such as in Saarland or in Switzerland, dated to the 6 th to 5 th century, torcs are simple rods of bronze or iron covered with a gold foil (6). Others take the form of a closed, wide ring cast in gold over a core, as found in female burials at Durkheim and Besseringen in Rhineland (7). The latter example has a large pro-

Fig. 6 Gold torc from Vilas Boas (Tras o Montes, Portugal). Note the little ducks in the large terminals. National Museum, Lisbon

Fig. 7 Buffer terminals and intermediate collars: detail of a bracelet showing the collar adorned with a fentale figure. From the Reinheim burial (end 5 th - beginning 4 th century $\mathrm{BC}$ )

6

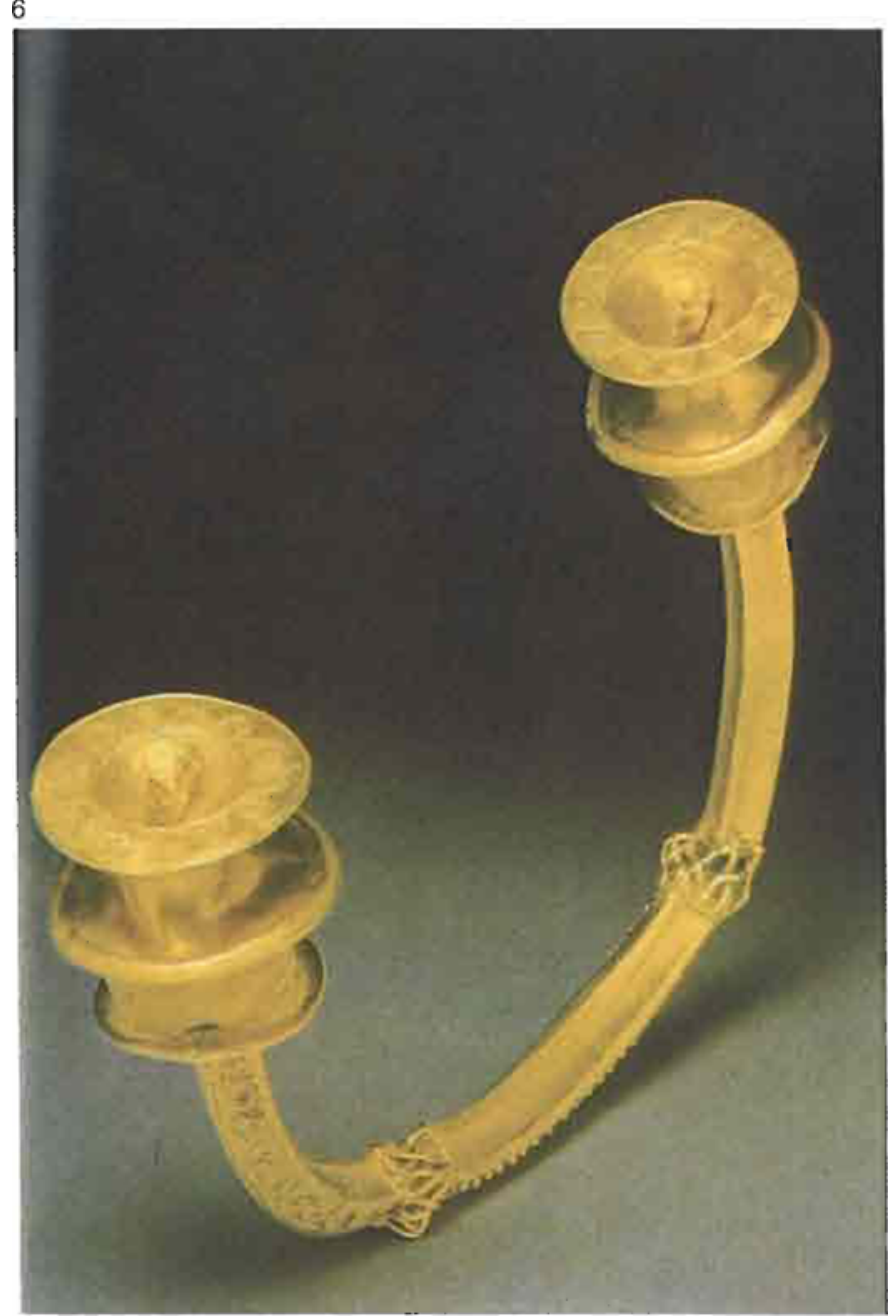

truding median cast-on decoration of birds facing each other, surrounded by baluster motifs. These torcs, because of their large diameter of around $200 \mathrm{~mm}$, may be easily slipped over the head.

Some rare gold twisted-bar torcs, with nearly closed, simple, flattened terminals, have been found in very different regions: one had been buried with numerous coins dated to the 1st century BC in a hoard discovered in the 18th century at Podmokoly (Bohemia) (8); another (Figures 3-4) was found north of Paris, at Soucy (Aisne) (9) together with another torc. With an external diameter of $145 \mathrm{~mm}$ and weighing $618 \mathrm{~g}$, it has a heavy and thick twisted appearance, but this pattern has been produced by progressive chiselling of a square-section bar (Figure 4). This chiselling technique, while not giving the same elasticity to the metal as hammering, has left the ring very rigid, and it is impossible to open it by twisting the ends (internal diameter: $109 \mathrm{~mm}$ ).

Apart from these rather infrequent types from Celtic

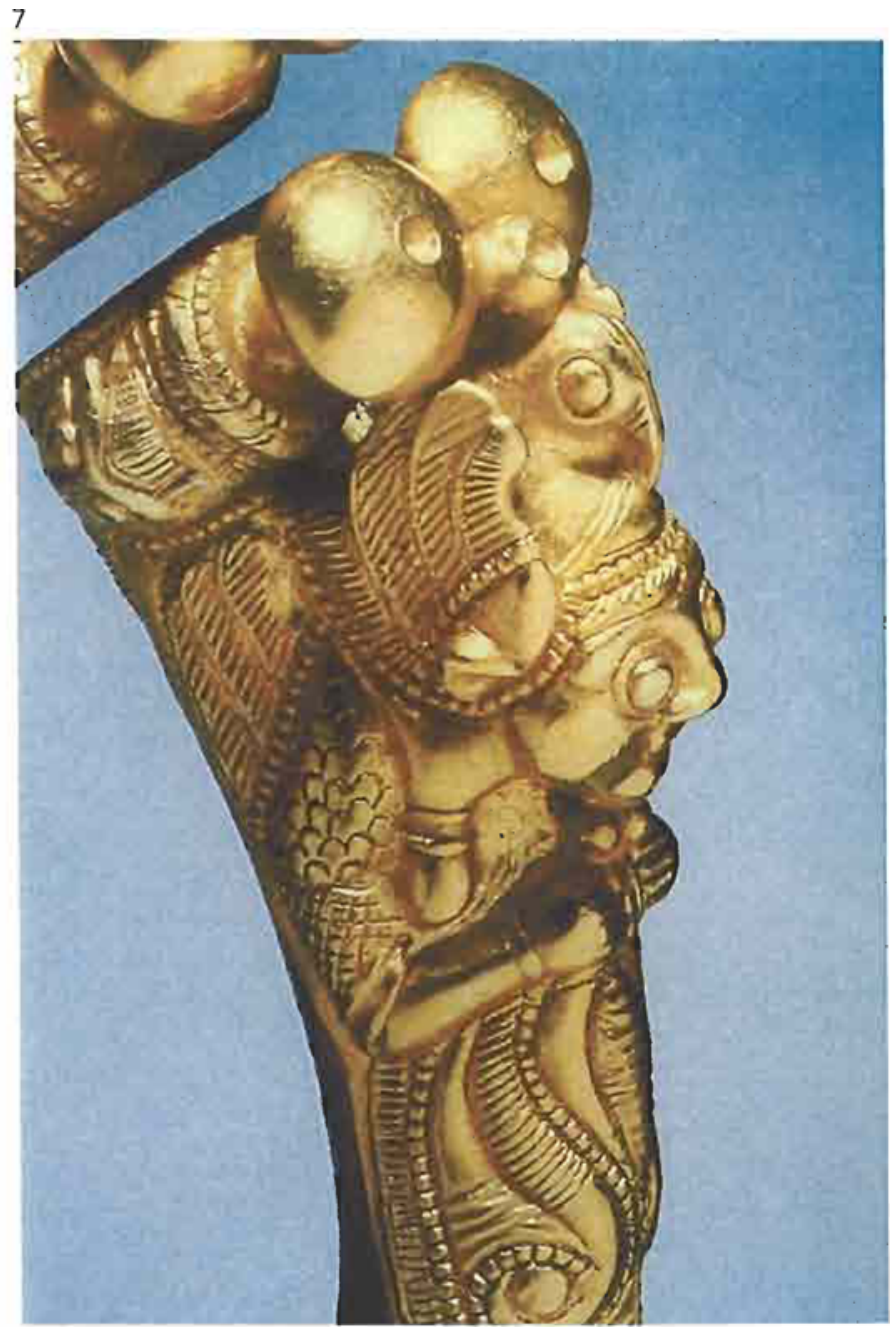


times, most of the torcs have more or less protruding terminals, the best stereotypes having 'buffers' - a term adopted by archaeologists because the profile is similar to the buffers of a railway wagon.

\section{Torcs with Voluminous Terminals}

Torcs with terminals soldered onto the rod or hoop appear rather early in the series. Dated to around $500 \mathrm{BC}$, the exceptional ornament of the Vix princess burial weighs $480 \mathrm{~g}$. Its prominent, bulky hollow terminals are sealed with soldered discs having a punched decoration (10). A little winged horse figure (representing Pegasus) is fixed on a mass of beaded wires.

The very widely separated terminals and general form of this jewel (Figure 5a) raise the problem of its use. It was found around the skull and so its use as a torc is still possible, although it is more probable that it was an element of head-dress. A group of gold torcs reminiscent of the Vix ornament were found in the northwestern part of the Iberian Peninsula (especially Galicia and Asturias) (11). The hoops of these torcs are usually hammered in massive gold or gold alloy, but sometimes they are of silver or copper plated with gold as, for example, the one found in Lanhoso (Braga province, Portugal). A group of these torcs have the lower part of their hoop covered with a spirally rolled wire imitating a torsaded pattern. The dorsal part of the hoop is left smooth, or is decorated with soldered filigree (see Figure $5 b$ ).

The buffer terminals of these Iberian torcs are very voluminous, with stereotyped biconical shapes (Figure 5), and are made of superposed, soldered, bent cylindrical elements. Their terminal transversal discs are decorated with stamped and punched patterns, sometimes also with filigree and granulation (11).

\section{8}

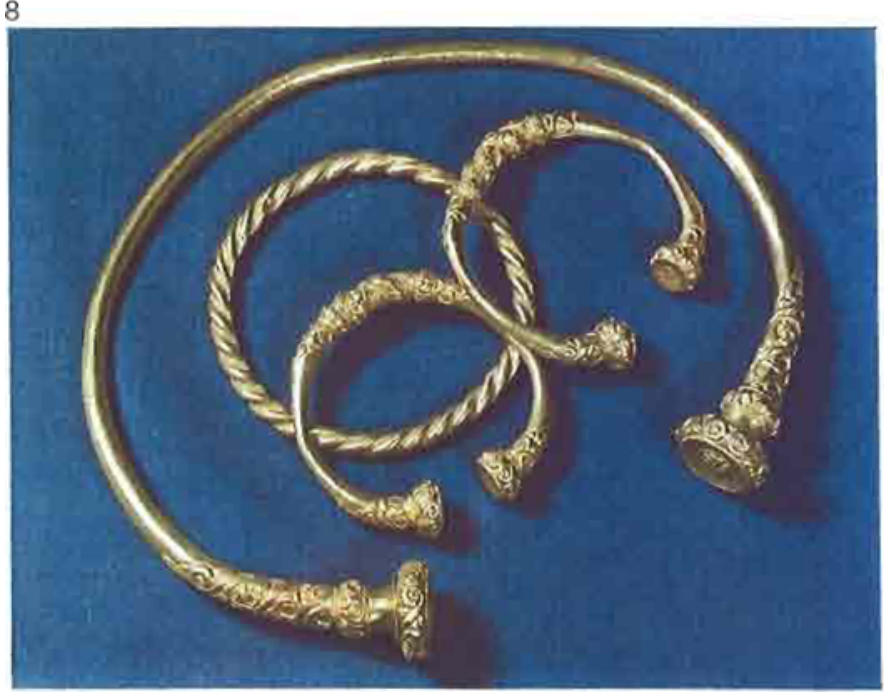

The Vilas Boas (Tras o Montes) torc (12), shown in Figure $6(387 \mathrm{~g})$, is an exceptional example because of the little soldered figures of ducks covered with granulation. The hoop of this torc is made of three hollow sections joined by soldered wires.

Another frequent type of terminal takes the form of pointed pears directly joined onto the ends of the hoop. Some damaged examples of such terminals on silver necklaces from Palencia (1st century BC) (13) are constructed from two shells joined halfway up the pear.

These Iberian torcs are often found in treasures from Castros - hillforts occupied from the Late Bronze Age till the Roman Age, and it is difficult to date them precisely. However, the example from Vilas Boas, with its decorative ducks, presents a typically Hallstattian* (ca. 6th century BC) motif. The Iberian torcs with terminals in the form of pears, and the rarer examples with cast 'bell' terminals (which are often decorated with filigree and granulation in addition to stamped and punched motifs) may have originated later.

\section{* The Halstattian period is the name given to the 1st Iron Age from around the 7th to the end of the 6th century $B C$, from a well-known cemetery in Hallsatt, Austria, es- pecially with reference to cultures in western central Europe.}

Fig. 8 Buffer terminals and intermediate collars: gold torc and bracelets from the Waldalgeshein (Rhineland, Gernany) burial (late 4th century BC). Landesnuseum, Bonn

Fig. 9 The Sintra gold neckring (Portugal), with a detatchable infermediate element (8th - 7th century BC). British Museum, London

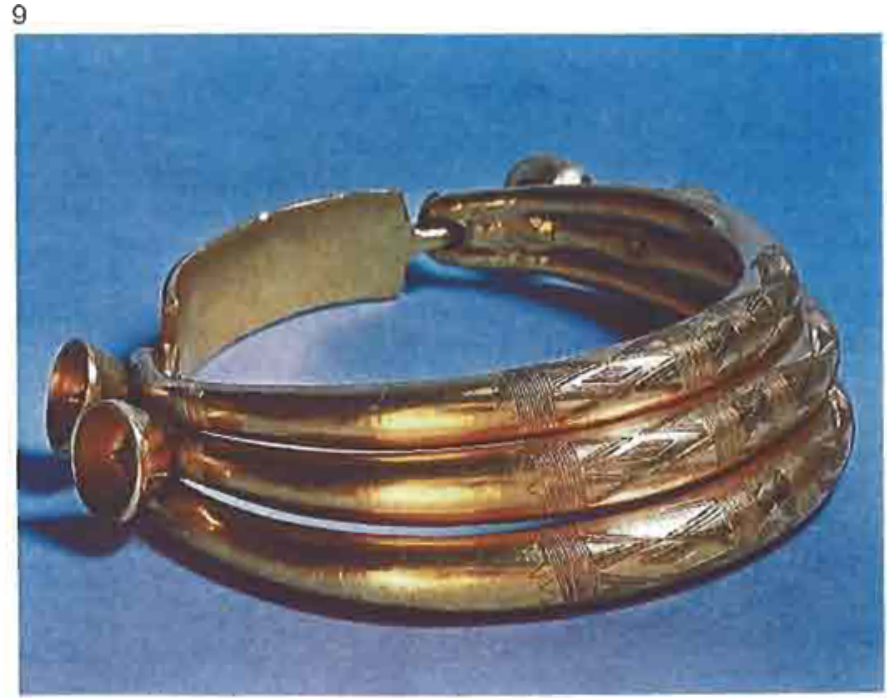


10

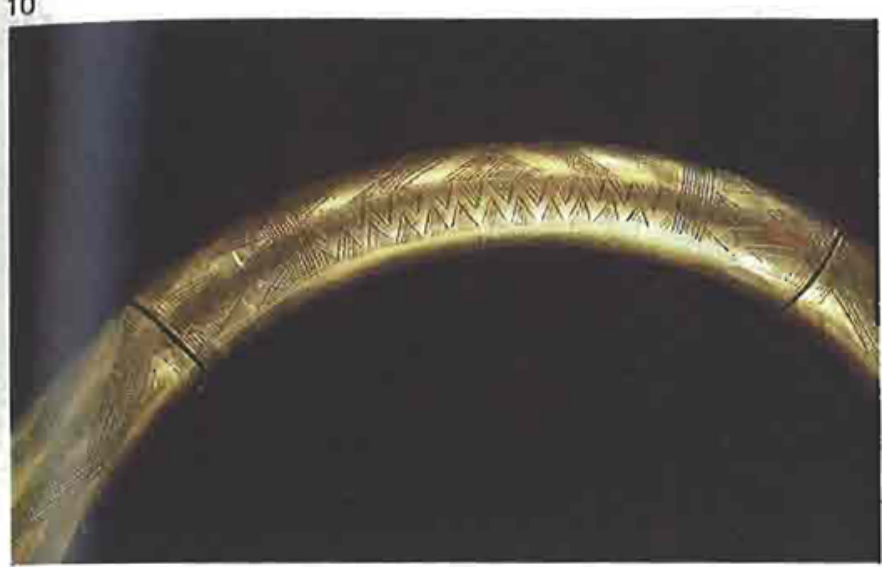

Fig. 10 Detail of the detatchable intermediate clasp-piece on the Evora torc (Portugal). Musée des Antiquités Nationales, St-Gernain-en-Laye

Fig. 11 Two torcs with a tenon and pin fastener, from the Erstfeld treasure (Switzerland, late 4 th century $\mathrm{BC}$ ). Landesmuseum, Zurich

On average, the Iberian torcs weigh between $400 \mathrm{~g}$ and $1000 \mathrm{~g}$. They are placed around the neck by slightly twisting the terminals apart; many examples have a very wide space between the terminals that facilitates this.

The Vilas Boas torc (Figure 6) is made in a gold alloy of 22 per cent silver and 1.7 per cent copper. Some analyses have emphasised the large variation in gold content of the alloys used for gold torcs. The analyses performed to date (14) separate them in two principal groups: those with 25 to 50 per cent silver and 15 to 45 per cent copper, and others having up to 25 per cent silver and less than 5 per cent copper (alloys with low malleability).

\section{Torcs with Buffer Terminals}

In the Atlantic region, some early heavy gold neckrings (around $600 \mathrm{~g}$ ) have been found in Brittany, Portugal and Spain. Decorated with grooved patterns, they have been hammered from an ingot into a massive hoop. The ends of the hoop have been transversally hammered to form little flat buttons or buffers. These torcs have a traditional form inherited from Bronze Age goldwork; indeed, some might be dated from the 8 th to 7 th century $\mathrm{BC}$, which is the very beginning of the early Iron Age (e.g. finds at Berzocana in the province of Caceres (15), and at Baioes, province of Beira Alta, Portugal (16)). Some others, with a thinner section, seem to be from a slightly later period (e.g. a find in the province of Burgos and Lerida, Spain) (17).

From the 5 th century $\mathrm{BC}$ onwards, some gold neckrings with decorated protruding buffer terminals also have a decorative pattern on the part of the hoop adjacent to the terminals. Usually, the pattern is cast and finished by chiselling.
On some of these examples, the buffers seem to have been cast together with the hoop (Oploty in Bohemia; Maschalm, in Austria) (18). This can be seen from the way they have broken, again possibly resulting from use.

One torc with a massive hoop and buffers, dated to the middle of the 4 th century $\mathrm{BC}$, comes from a rich female burial in the Filottrano cemetry (19), northern Italy, where many Celtic Senones peoples were settled. Its terminals were tightly closed. They are soldered onto the expanded ends of the hoop. Both hoop and buffers seem to have been cast.

Some torcs of this type, from St-Gerand in central France, or Gorni Zibar, Bulgaria (20), for example, also have separately prepared (cast) buffers soldered to the hoop. Their terminal discs are also soldered to the buffers, probably in the final stage of manufacture. We should bear in mind that several finds of isolated terminals have been made in the Iberian Peninsula and in Brittany. In the latter case, there is a buffer made of two soldered shells, with

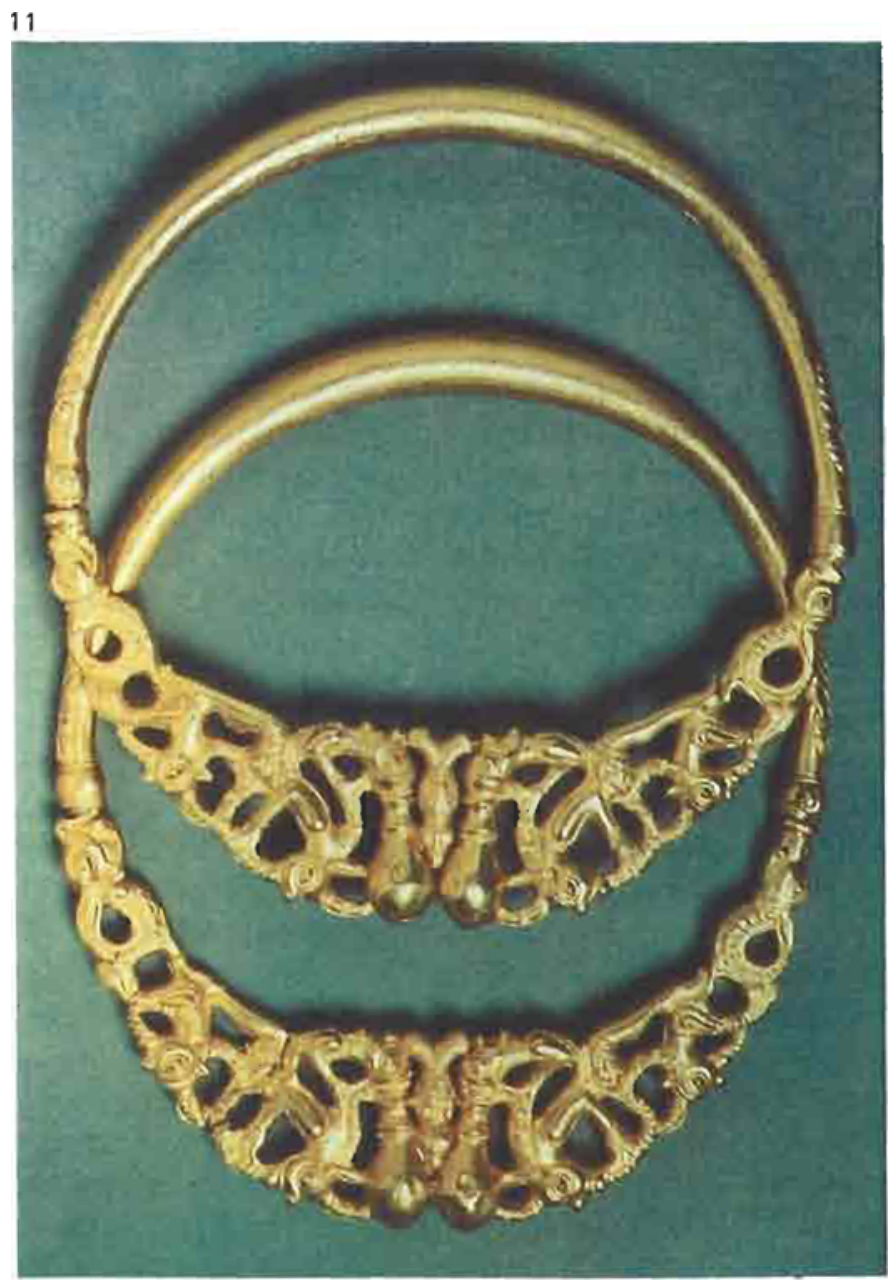


traces of soldering at the hole where it had been fixed on a circular rod (21).

\section{Tores with Buffer Terminals and Intermediate Collars}

A small group of torcs from the late 5th and early 4th century $\mathrm{BC}$ have their buffer terminals connected to an intermediate collar instead of being directly soldered to the hoop. One of these was found in the rich grave of a princess (end 5th to early 4th century $\mathrm{BC}$ ), in Reinheim (Saarland) (22). This torc, as well as a pair of gold bracelets from the same burial, has a very original decoration depicting a woman's head. Radiography (23) of one of these bracelets has clearly shown evidence of this construction, with intermediate collars featuring a complex decorative pattern with human figures which, despite its indigenous expression, indicates some Mediterranean influence: at each end of the hoop, a separately cast hollow collar has been added, probably by joining. A flat buffer-like terminal has been added on top of the head (Figure 7).

Approximately the same construction is seen in a torc found at a distant site (Baiceni, Rumania) in a treasure from the mid-4th century BC. It has a circular collar at each side of the round-sectioned ring, in which a horse's head motif has been introduced.

Indeed, this construction, with additional collars before the ornamental terminals, has been largely used in classical goldwork bracelets with figurative terminals such as those mentioned above. This feature has also been adopted on Scythian torcs for fixing the large terminals decorated with complete figures of animals, or hunting or riding scenes (25).

Returning to the Rhineland area, another very rich burial of the late 4th century BC, in Waldalgesheim (26), has also provided a large torc with a collar at each end of its rounded massive hoop (Figure 8). But in this case the terminals are of a local, more abstract, decorative character, with spiral and triskele patterns. Again, these elements have probably been made separately and joined by soldering (collars to the rigid hoop, buffers to the collars and the terminal disc to the facial centre of the buffers). The gold composition of torcs from Reinheim and Waldalgesheim is around 3 to 4 per cent silver and 0.3 to 0.5 per cent copper, similar to other contemporary objects from the same area.

\section{Torcs with Hook Clasps}

\section{Torcs with Clasps}

Many twisted gold torcs of the Bronze Age have hook terminals, and some small twisted-ribbon torcs with hooks were still being produced in Scotland and Ireland during the Celtic Iron Age. One example of this type has been found in Clonmacnoise (Co. Offaly), with another having the more typical buffer terminals. The functional character of these torcs with hook clasps accounts for their being widespread geographically and in time. One found in Kosd (Hungary) is dated to the 3rd to 2nd century BC (27). Others, from southern Spain, made with tressed wires (28), and one from the Broighter hoard (Ireland), with a heavy twisted hoop (28), are from a later period (1st century BC).

Being similar to torcs formed from unbroken circular hoops or simple open rods, torcs with hook fasteners are not really typical of the Celtic Iron Age. Hence they will not be discussed further in this article. However, torcs with buffer terminals and hooks are particularly noteworthy (see below).

\section{Torcs with Detachable Intermediate Elements}

The hoops of this group of torcs have intermediate elements or sections with tenons or hooks at each end that fit into corresponding openings in the body of the torc. This construction is found in massive Portuguese torcs from the Late Bronze or Early Iron Age. Examples include those from Sintra (1.2 kg) and Evora (2.1 kg), shown in Figures 9 and 10 respectively, and from Coimbra (1.8 kg).

This is an archaic form of clasp which is also found on bronze bracelets from the Bronze Age (ca. $1200 \mathrm{BC}$ ) (29). The technique of manufacturing these torcs - by hammering a large cast bar - is another heritage from earlier technologies.

Along the joints of the three solid bars of the Sintra torc (8th to 7th century BC), there are no traces of gold-copper alloy or copper salts. The presence of copper would have been expected if the widespread Mediterranean techniques had been employed. Instead, it seems that a more sophisticated technique was used, involving over-casting, or heating a gold plate in the required position (30).

\section{Torcs with Tenon and Pin}

The four torcs from the treasure found in Erstfeld (Switzerland) (31) are dated to the late 4 th century BC. Three of them have a similar and very original decoration mixing fantastic human figures and abstract plastic patterns. The principal technical interest of these torcs is in that they are made in two main parts, easily detachable from each other. Each part has a tenon and a hollow smooth rod, at the end of which is a short internal tube for receiving the tenon from the other part. The tenons, projecting from each end of the decorated area, were made by hammering a thick sheet of gold and inserting it tightly. One of the tenons and its corresponding socket have aligning holes, which allow the closed torc to be locked with a pin (Figure 11).

Other examples of torcs with this type of clasp come from a completely different part of southwestern France. However, they have another, very characteristic, construction and decoration. A small torc from Montans has a thin, flexible, hoop made of four twisted wires wound around 


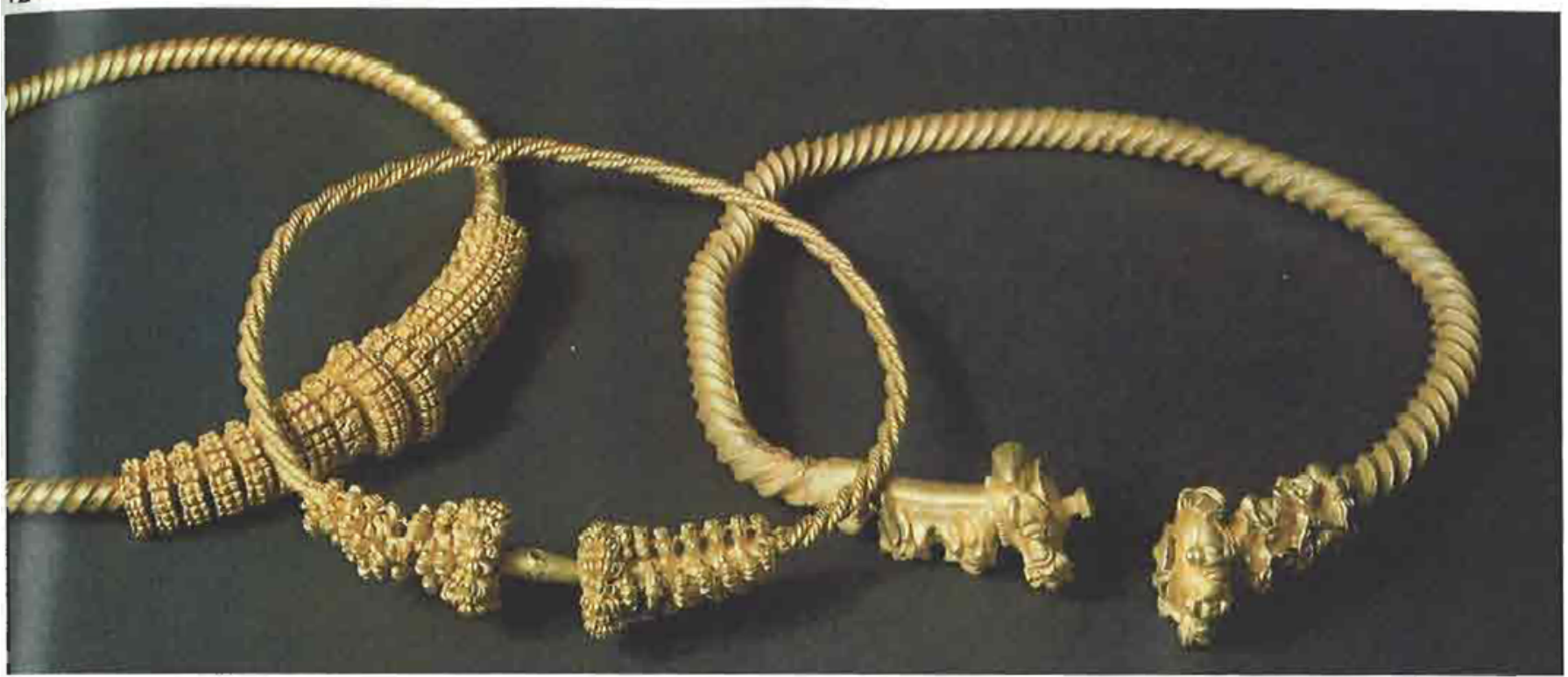

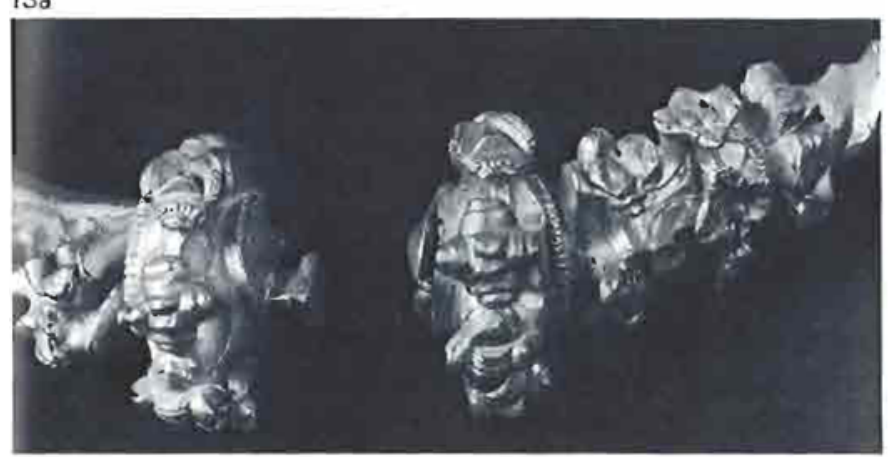

$13 b$

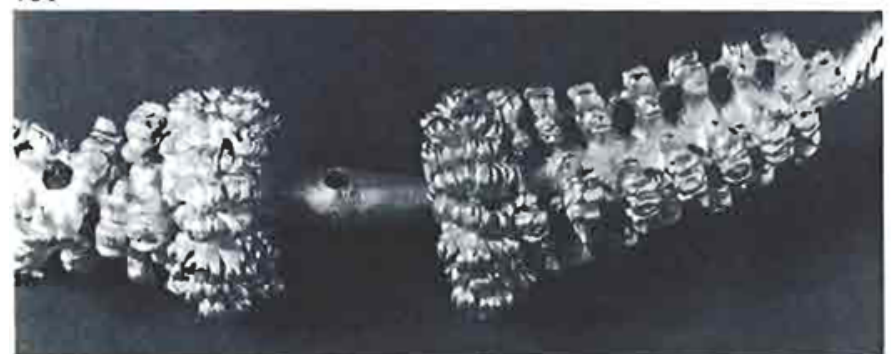

14

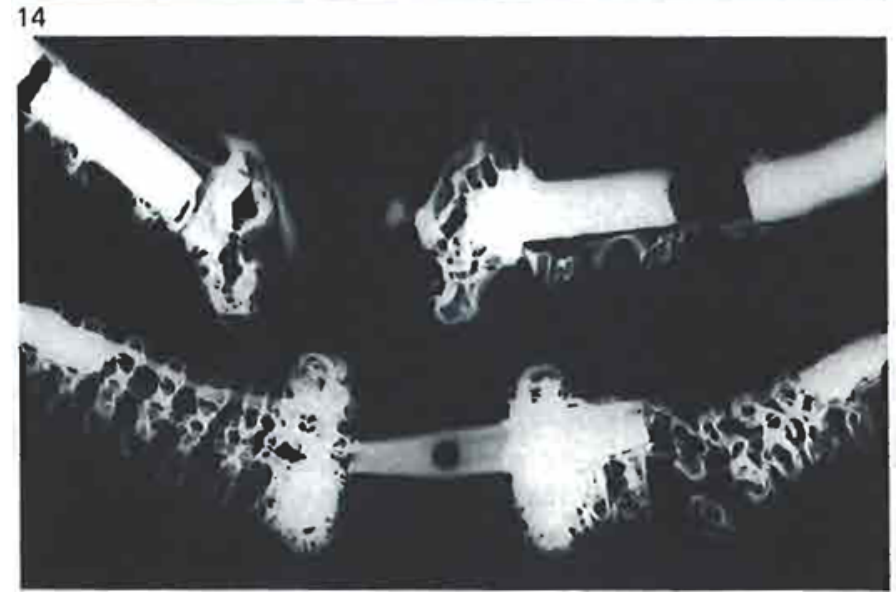

Fig. 12 Torcs from France with different types of terminals. From right to left: Civray (Indre-et-Loire); Montans (Tarn); Fenouillet (HauteGaronne). Musée des Antiquités Nationales, St-Germain-en-Laye. The original of the Fenouillet tore is in the Museum of Toulouse, and this photograph is of a copy

Fig. 13 Details of terminals. a) Torc from Civray; b). torc from Montans

Fig. 14 Radiographs of the terminals of the Civray torc (top), and Montans (bottom), taken in the Laboratoire de Recherche des Musées de France, Paris

each other (Figure 12). Separately cast collars are clamped to the ends of the hoop (see Figures $13 \mathrm{~b}$ and 14 for constructional details). The collar has a schematic floral pattern on the outside which is so ornate that the joined buffer cannot be distinguished. The torc is fastened by inserting the tenon into the opposite collar, and securing it with a pin (Figure 13b).

The torc from Montans is archaeologically not well dated. Torcs from neighbouring sites - Fenouillet (six torcs) and Lasgraïsses - feature similar decorative motifs, but a rather wider variety of clasp systems. One of the neckrings from the Fenouillet treasure also has a very small diameter, like the Montans torc $(125 \mathrm{~mm}$ and $120 \mathrm{~mm}$ respectively). Even so, because of their flexibility, these torcs were probably worn around the neck.

Both are made of very pure gold (Montans: 0.6 per cent silver and 0.07 per cent copper; Fenouillet: 2 per cent silver and 0.2 per cent copper) (32).

Torcs with Buffer Terminals, and Hook and Split Clasp Only a few of this type of torc have their buffer terminals 
soldered directly to the hoop. Two of them - including one from Niederzier (Rhineland) - are perfectly preserved (33), and were made from sheet rolled into a flexible tubular section. They had been buried with gold coins of the 1st century BC. The type of construction and clasp of these torcs make them easy to wear.

The torc found at Soucy (Aisne, France) (34) is very much heavier: $482 \mathrm{~g}$ and external diameter $145 \mathrm{~mm}$. It is made of three massive rods of circular section, twisted together and joined before the almost spherical buffers were soldered onto them. The joint is hidden by a wire binding, while the clasp consists of a flat hook which engages in a slit or socket on the opposite buffer (Figures 3 and 15). This torc from Soucy is very rigid, and does not have the same functional character as the flexible Niederzier neckrings.

Other torcs have cast collars preceding the buffer terminals carrying the clasp system. One torc of this type, recently discovered in France at Civray-de-Touraine (Figures 12-14), has been extensively studied (35), and radiography (Figure 14) has revealed revealed interesting constructional details. The hoop was made by tightly twisting together three bars of rectangular profile. At their ends, they have been hammered to a thinner, circular section onto which the collar was soldered. A slight increase in copper content (about 1.5 per cent) in the region of the joint discloses the joining process employed: copper diffusion bonding. This collar has a floral decoration, is hollow, and has been cast separately (a granular, metallic structure can be seen inside). The goldsmith has pushed the collar over the joint, to provide a tight fit and continue the twisted pattern.

The decorated parts of the buffer terminals have also been cast separately as open rings and then fitted to the free ends of the collars. Through the open buffers, the goldsmith was able to align the segments. Again, copper diffusion bonding was used to reinforce the construction, as indicated again by a slight increase in copper content. The join was concealed by soldering a beaded wire around it. Finally, discs carrying the clasp system - comprising a cast hook and corresponding triangular aperture (Figure 16) were added. The open ends of the buffers and the edges of the discs have been bevelled to obtain a good, matching fit. Once again, these elements have been joined together by copper diffusion bonding, and the structure of the joint line is clearly visible in SEM (Scanning Electron Microscopy) photographs (Figure 17).

However, radiography of a torc from Civray shows small solid gold bars inside the collars, perhaps to ensure sufficient weight, or to strengthen the terminals. These bars were probably introduced before the clasp assembly was soldered in place.

The different stages of construction analysed here involve several heating steps (at least three for each termi- nal). It is possible that the associated annealing effect made the heavy $(340 \mathrm{~g})$ torc sufficiently flexible for putting around the neck.

A torc in the Fenouillet (Haute-Garonne) treasure mentioned earlier has similar features, but its buffers are practically indistinguishable under the floral decoration (Figure 12).

The hoop of the Tayac torc, found with coins of the early first century BC, now has open-ended buffers, which previously may have been closed with a clasp system. The torc is also made of several rods twisted together, with large buffers terminals soldered onto short collars (36).

Torcs of this type are small (Civray: $135 \mathrm{~mm}$; Fenouillet: $162 \mathrm{~mm}$; Dronninglund in Denmark: $162 \mathrm{~mm}$ ) (38), with the exception of the Havor (Sweden) torc, which has a large diameter $(240 \mathrm{~mm})$ allowing it to pass easily over the head (37).

The different torcs in the Fenouillet treasure with this type of clasp system - both with and without muffs - all have the same gold composition: 0.5 to 2 per cent silver and around 0.3 per cent copper. The Civray torc is also very pure: 0.7 per cent silver and 0.4 per cent copper. The Dronninglund torc, with 11 per cent silver and 4 per cent copper, is made from a different type of alloy. Its very tight form seems to have been definitively closed.

\section{Torcs with a Rotating Dorsal Muff}

These torcs were probably very easy to wear, and to put on or take off. Their very light but voluminous hoops are composed of two curved tubes made by hammering from sheet. One end is engaged in the lateral opening of a buffer, while the other, at the dorsal area, terminates in a detachable ring or muff. Examples of torcs of this type are well dated to the end of the 1st century BC - one from the Basle treasure, that of Frasnes-les-Buissenal (Belgium), or those of Snettisham (Norfolk), where the torcs were abandoned with gold coins (39).

On the torc from the Basle hoard (Figure 18), a pair of very wide buffers (diameter $71 \mathrm{~mm}$ ) are attached to each other in a manner allowing them to turn. In constructing this rotating pair, first one inner shell had the border of its central hole folded out and over the prepared rim of the second inner shell's central hole. This formed the central rotating link. An outer shell was then soldered onto each side, as shown by the radiograph in Figure 19. The central segments of the hoop of this torc, which had to be very large, have not been found. However, we can imagine how easily the tubular rods could be moved for opening the neckring, either by inserting them into the buffer or, if soldered to it, by twisting them in opposite directions.

Half of the other torc from Basle has been found, but it has been extensively restored, and it is not possible to check its construction. 


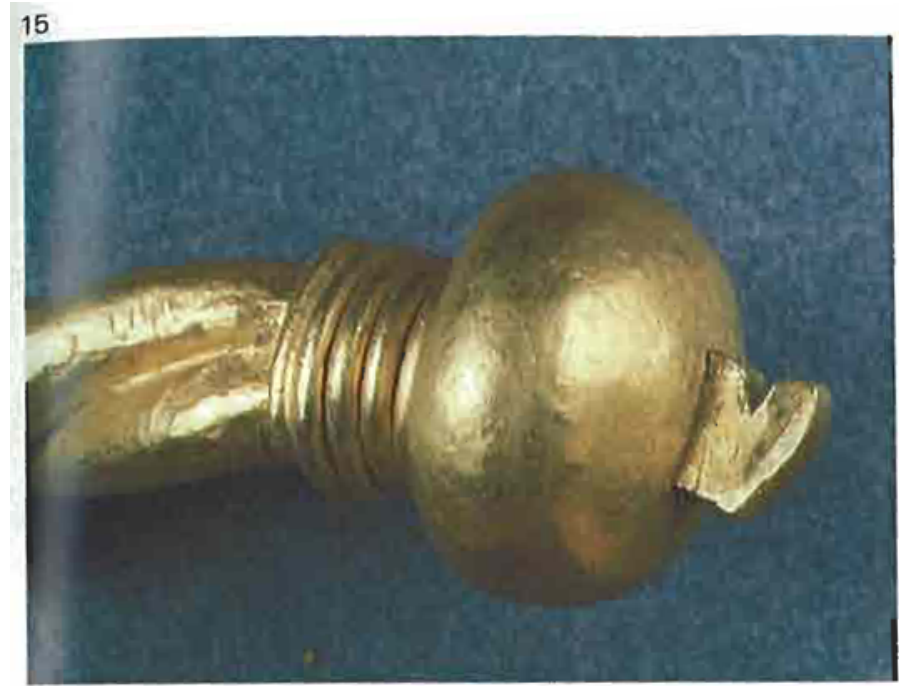

16

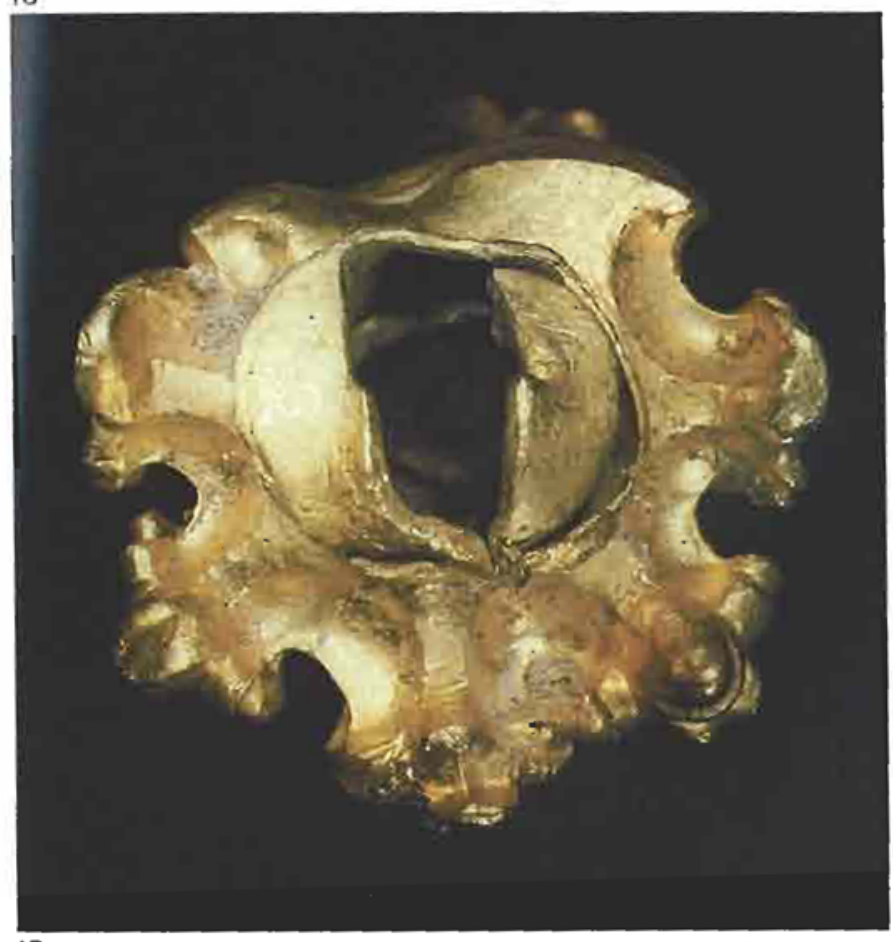

17

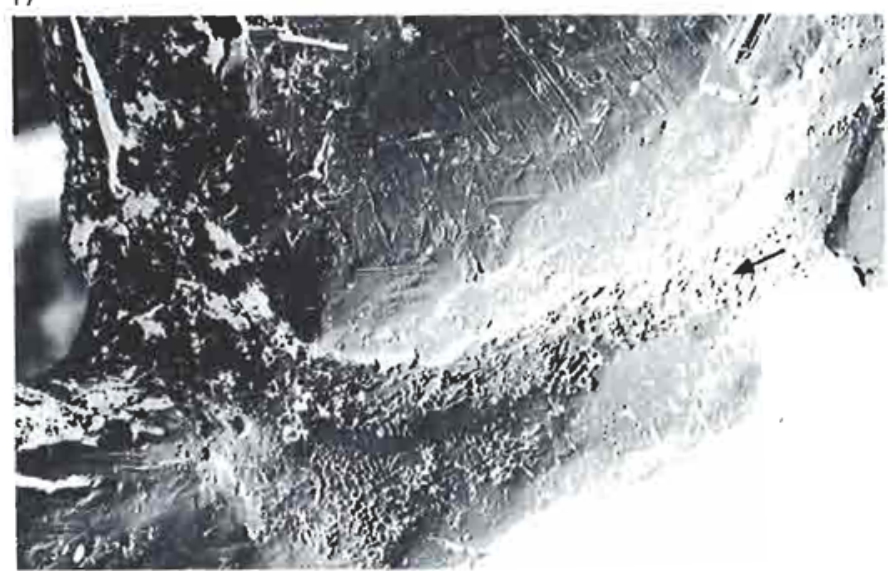

The Mailly-le-Camp (Aube, northern France) torc was an isolated find (40). Its buffers are soldered to each other through a narrow band with folded borders (Figures 18$21 a, b, c)$ containing, in its angles, two wires (obtained by twisting, as indicated by traces of helicoidal markings). On these wires, constituting a bas relief, spirally rolled twisted filigree has been soldered, and on the top of the spirals, there is a double beaded wire with granules dispersed at regular intervals (Figure 21a).

At each side of this pair of joined buffers the hollow tubular rods are inserted. However, contrary to the previously described function of the buffers, one rod is detachable (its decoration at this level is very worn). The other rod has its border cut into a fringe. This fringe is turned back (Figure 21b) over the internal border of the buffer, thus holding the rod in position while allowing it to rotate. Supporting the opposite ends, which had to be held in place by a collar, is a circle of soldered wire.

On the Basle torc, a flat ring performs the same function. All these hollow curved tubes are very light and fragile. They were originally supported internally, and the remains of an iron rod have been found in the torcs of Mailly and Frasnes-les-Buissenal (Belgium). This rod itself has a clasp, so the tubular gold stems are only a decorative cover. The remains of a core found with a mixture of wax around the iron rods probably indicates that the inside was filled after the metallic setting was finished. This filling must have provided weight and resistance to these light torcs $(122.8 \mathrm{~g})$ of relatively pure gold. Those from Basle and Mailly have 3 to 5 per cent silver and a maximum of 1 per cent copper.

\section{Torcs with a Hybrid Clasp}

A few torcs display a combination of some of the systems already discussed. In the Fenouillet hoard, there is a small neckring with a cast floral decoration covering the entire visible surface, including the hollow stem (Figure 22a). The buffers are closed by a hook. However, this clasp can only be unlocked if first a dorsal tenon and pin joint is opened and one arm twisted through $90^{\circ}$. This turns the

Fig. 15 Detail of the torc from Soucy (Aisne, France) showing the male element of the clasp. Musée de Cluny, Paris

Fig. 16 Torc from Ciyray (Indre-et-Loire, France). Detail of the face of the female clasp; the disc with the split is damaged. The outline of the hollow nuff may be seen through the hole

Fig. 17 SEM micrograph of the torc from Civray - detail showing the netallic melted structure (arrow) at the narrow line where copper diffusion bonding was used along the border of the terminal disc supporting clasp 


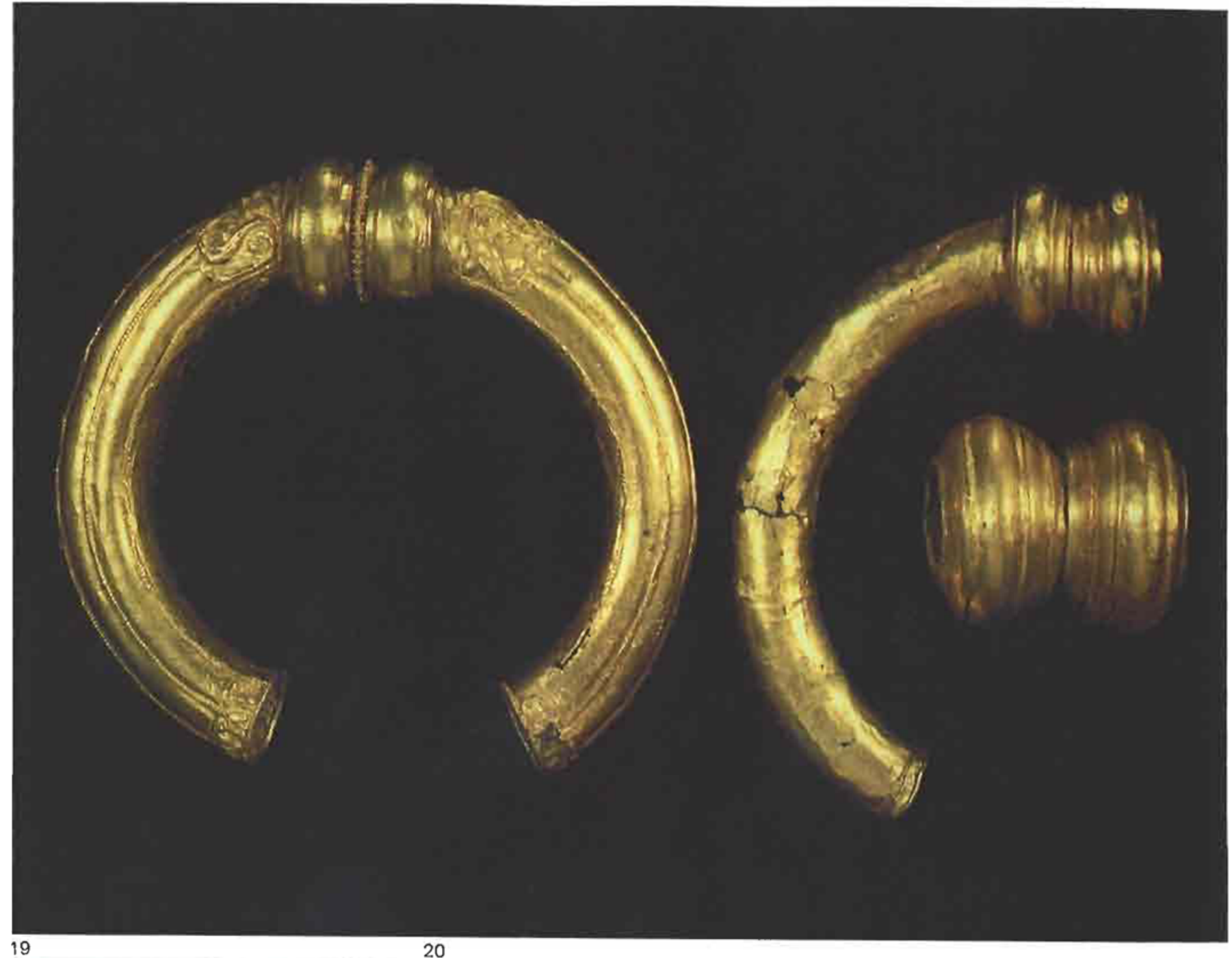

19

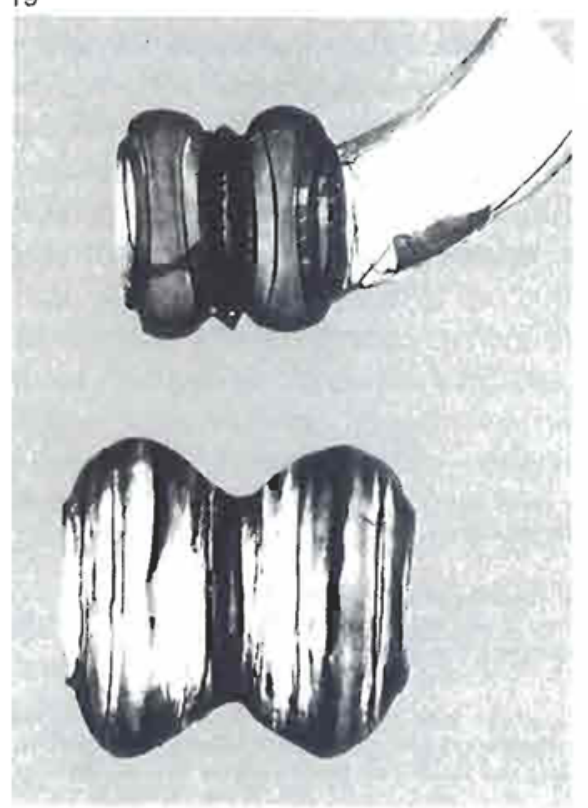

20
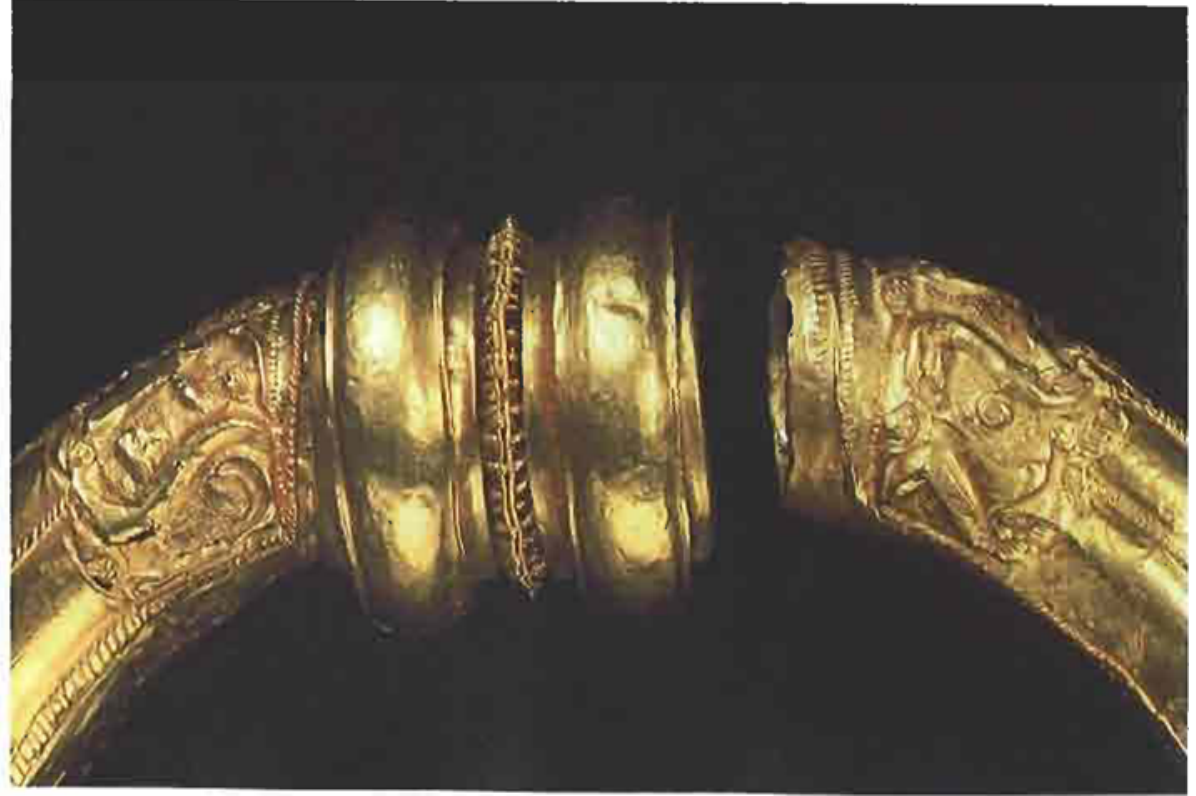

Gold Bull., 1987, 20, (1/2) 


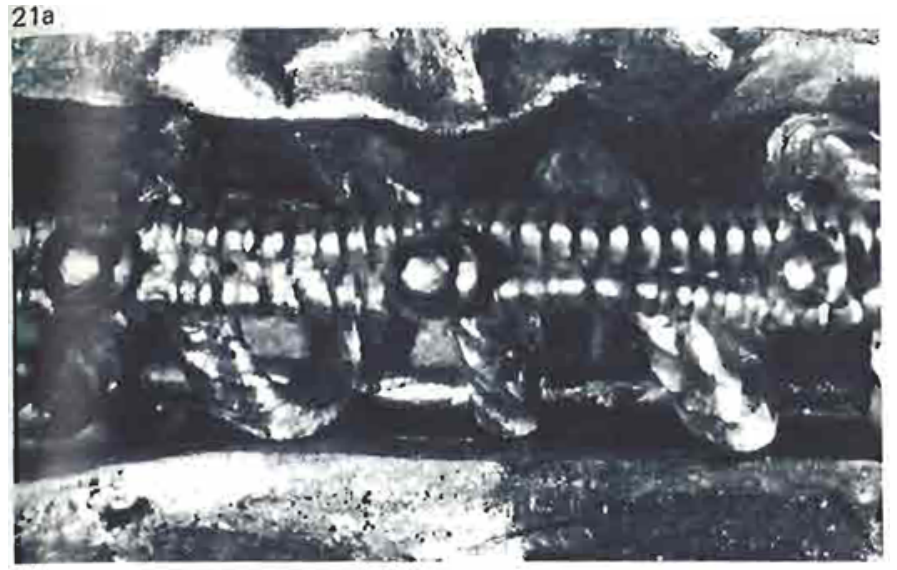

$21 b$

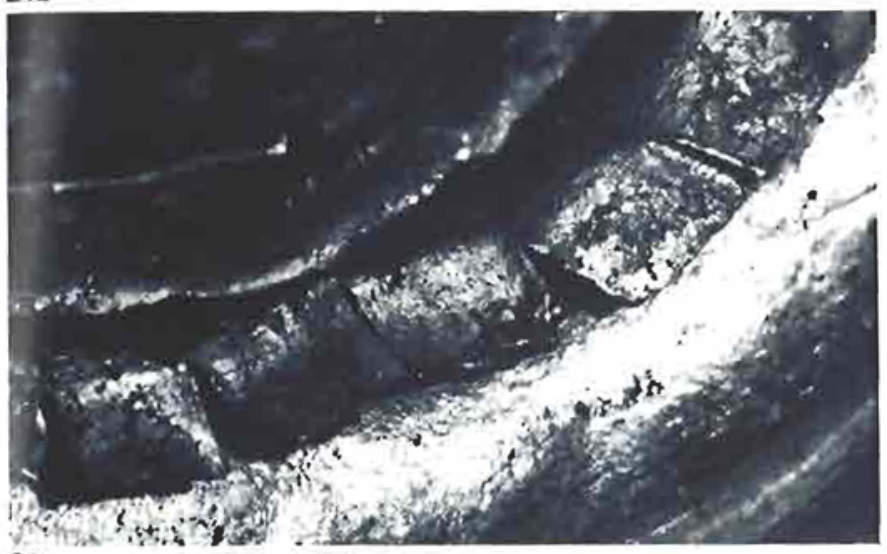

$21 \mathrm{c}$

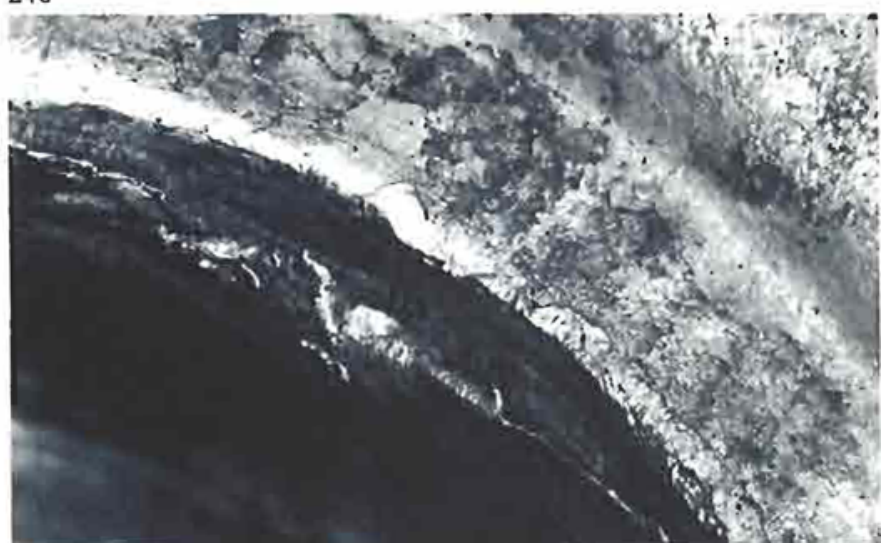

Fig. 18 Gold torcs with a rotating dorsal nuff. Left: from the Basle (Switzerland) hoard. Right: fron Mailly-le-Canp (Aube, France). Musée des Antiquités Nationales, St-Germain-en-Laye

Fig. 19 X-ray photographs of the buffers of the tores from Basle (top) and Mailly-le-Camp (botton)

Fig. 20 Detail of the frontal opening system of the torc from Mailly-leCamp

Fig. 21 Details of the construction of the torc from Mailly-le-Camp. a). Decoration of filigree, beaded wires and granulation on the niedian joining band; b). cut edge of one rod wedged in the buffer; c). soldered median band seen from inside the buffer hook into alignment with the slit, and it can then be removed.

The same type of complex construction appears on the Lasgraïsses torc (Figure 22b), found together with a bracelet. Dorsally, it has a very particular clasp: a flat hook which enters a complementary slit, as well as a movable tenon. The hook is unlocked with a $90^{\circ}$ rotation of the frontal clasp. On this torc from Lasgraïsses, again the visible surface of the stem is covered with a hollow floral motif, alternating with some cast twisted motifs between the flowers. The construction of this torc is reminiscent of that of the torc from Civray. On the inside, a transverseal line clearly shows where the cast collar was soldered onto the stem, even though the external differences are obscured by the decoration. The same order of stem-collar-buffer is maintained in construction, in spite of it not being apparent externally.

A torc from the same family, but found far away in Gajic (Yugoslavia), possibly had the same construction (41).

These rather small neckrings (the one from Fenouillet has a diameter of $130 \mathrm{~mm}$ and weighs $158 \mathrm{~g}$, while that of Lasgraisses is bigger - $170 \mathrm{~mm}$ in diameter) are made of relatively pure gold, containing only 1 to 3 per cent silver and 0.2 to 1.9 per cent copper. The copper may have originated from a join, but we do not know exactly from where the samples were taken for analysis.

Two torcs with a different hybrid construction come from Ireland. In the Broighter hoard (Co. Derry), a torc with tubular stems, similar to the one from Mailly-le-Camp, has a different setting: its curved stems are riveted to a short tube, or collar, preceding the buffers (Figure 23). A buffer-like terminal is attached to the front end of each hoop. The effect is that of a cylindrical drum with a broad flat depression running around it. The depression surrounding the left drum is decorated by a free-standing band of gold covered with transverse ridges, each composed of three pellets side by side. The depression on the right drum is now empty. The surface of each drum is made from a disc soldered to a poimt below the height of the rim. The disc on the left terminal is decorated with radiating ridges. A soldered, short cylinder projecting from the centre carries a flat T-shaped soldered tenon. The other (right) terminal has a protruding cylinder which faces the opposite disc. The gold plate that caps it has a circular depression with a slit in its base into which the tenon can be inserted. If the ends of the cylinders are then rotated, the clasp is locked, like a bayonet.

The other torc from Ireland was found in the Clonmacnoise (Co. Offaly) hoard. It has a diameter of $145 \mathrm{~mm}$, and is made from two half hoops of hollow gold tubing. At the back these are delimited by a box-like feature, while the front features a pair of buffer terminals (Figure 24). The 


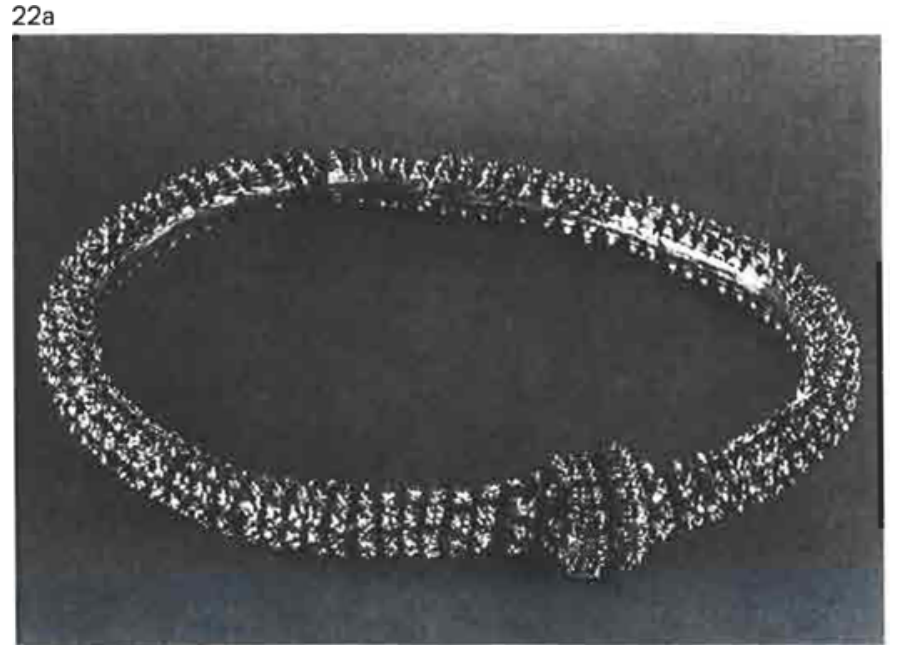

$22 b$

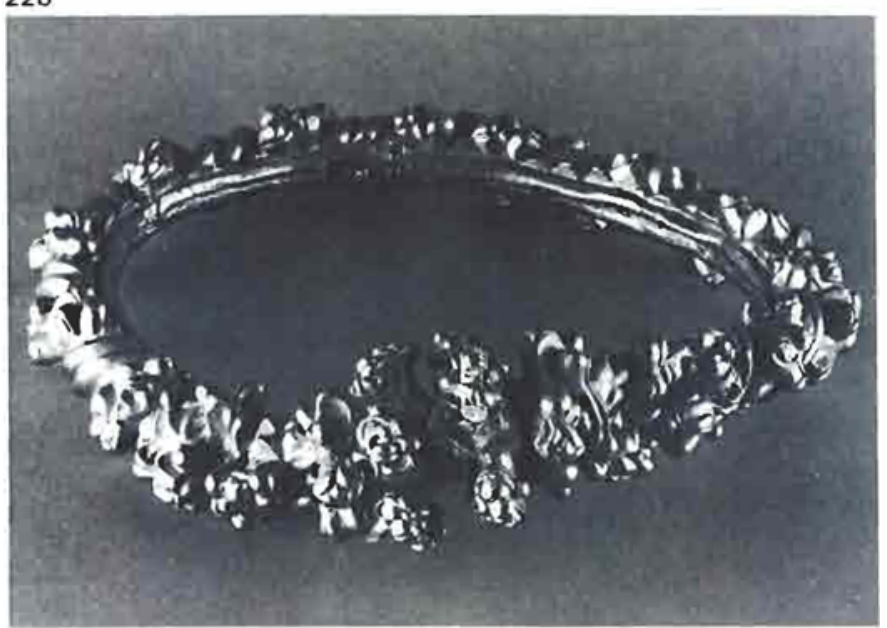

torc is closed by inserting the end of the right hoop into the 'buffer' and securing with a pin. Thus, the pair of 'buffers' are not actually functional in the true sense. At the back, the hoops have a terminal flange and then a constriction where they join a box-like element decorated with filigree (43).

These two neckrings are made from low gold alloys (Broighter: 26 per cent silver and 6.9 per cent copper; Clonmacnoise: 19 per cent silver and 2.5 per cent copper).

\section{Torcs with Loop Terminals}

This group of torcs, with large loop terminals, is essentially restricted to the British Isles. They are most frequent in Norfolk, from multiple hoards buried in Snettisham and Ipswich (14). Some specimens have also been found in Scotland. The large hoops of these torcs are characteristically produced by twisting two heavy, thick hammered bars of polygonal section. Alternatively, bundles of twisted wires are used. The ends of the twisted rods are capped with
Fig. 22 Gold torcs with a hybrid clasp system. a). Torc from Fenouillet (Haute-Garonne, France); b). torc from Lasgraïsses (Tarn, France). Musée St-Raymond, Toulouse

heavy terminals in the form of a large loop, usually directly cast-on to the twisted ends (Figure 25a,b). The visible traces of gold which flowed into the spaces between the twisted wires, together with experimental trials made by colleagues at the British Museum, indicate that the overcasting was done by pouring metal into a clay mould fixed at the ends of the twisted segment.

Sometimes these torcs have their terminals pulled open, while others have relatively closed terminals. The thickness of their hoops (the Ipswich torcs weigh from 858 to $1044 \mathrm{~g}$ ) makes their use as neckrings difficult, although possible.

The composition of the torcs from Ipswich is not very homogenous. The twisted rods contain 11 to 28 per cent silver and 0.3 to 6 per cent copper, while the looped terminals contain 10 to 17 per cent silver and 0.4 to 12 per cent copper. A slightly copper-rich alloy may have been used for the ends as its lower melting point allowed over-casting without risk of deforming the rods.

Mention should be made of another group of late torcs from a different region, which also have looped terminals but of more modest proportions. Some of these torcs, from the Iberian Peninsula, are made from stressed wires witk their ends hammered flat and folded to form small loops This type are found in gold, but were more frequently made from silver during the 1st century BC (examples coms from the hoard at Castelo Branco in Portugal, the gold one containing 14 per cent silver and 5.2 per cent copper).

\section{Torcs and Gold Technology}

Most of the torcs found show signs of having been worr before they were buried. As already mentioned, buriec torcs may occur in hoards, with and without other valu ables, or as isolated items, or in human burials.

However, the physical structure of some of the torc: makes it unlikely that they were ever worn - either becausi they are too rigid or too small to be put around the neck Examples of such torcs are from Soucy (Aisne), Dronnings lund (Denmark) and Tayac (Gironde, France).

It is probable that these torcs had other functions of uses, such as in the adornment of statues or altars. Torc: held by representations of deities, themselves wearing torcs, and the frequent findings of more than one torc, or of a torc with other gold objects (such as a gold ring), ars indications of these religious or ceremonial roles of torcs These secondary uses (such as in ceremonial burials) ma! also apply to torcs that were initially worn. 
Barbarian torcs generally conform to a standard constructional design: rigid body and protruding terminals. The large variation in the types of terminals reflect cultural features, as mentioned for the Scythians. The Celts tended to preserve the abstract character of their decorations, a tendency repeated in the Iberian peninsula, although with terminal forms different to the pure Celtic buffers. Techniques in the Iberian peninsula frequently show signs of Mediterranean influence. Exceptional figurative decorations are found in the areas of Vilas Boas (Portugal), Reinheim (Germany) and Erstfeld (Switzerland). However, these influences, except the use of beaded wires, are rarer in France.

The classical types of torcs, with their massive hoops and buffer terminals, appear between the 5th and 4th centuries BC around Rhineland, Bohemia and the Po valley. Already at that time, both constructions - with or without an intermediate collar or muff - were produced. However, clasp systems seem to belong to the later examples. The earliest clasps were designed to exploit the elasticity of gold. Later systems used more sophisticated mechanical fittings.

No torcs have been archaeologically attributed to the 3rd or 2nd century BC. But we know, from Hellenistic sculpture, that torcs were worn at that time by Celtic warriors. Several explanations could account for the lack of torcs from this period: looting by enemies, careful preservation through generations, and remelting for early coinages.

However, on the late torcs, accurately dated to the 1st century BC, there are a wide variety of forms and clasp systems, indicating technical sophistication and, presumably, advances over earlier designs.

This variation in one type of object marks a new phenomenon found in Iron Age goldwork. Five centuries earlier, only one technique was used in Europe to produce sheet-gold neckrings for the early Celtic princes (44).

The multiplicity of techniques in use at the time of Roman expansion in Europe indicates a new spirit, requiring free imagination, which contrasts with the stasis earlier, archaic times. Contact with Mediterranean goldsmiths probably influenced designs, especially in Gaul.

In a group of torcs from southwestern France, the gold purity is almost 100 per cent in three specimens (from Fenouillet, Montans and Civray), while others from this area contain 1-2 per cent silver and around 0.5 per cent copper An emission spectrographic analysis has been carried ou on the tores from Montans and Civray (45) (see Table I).

The purity of this gold makes one wonder if it $h \mathrm{~s}$ been refined, although alluvial gold in southern France nay be very pure (samples from the Hérault and Var rivers are 99 per cent gold (46)). This is difficult to verify, as these torcs from southwestern France are enveloped in legends con-
Fig. 23 Gold torc from Broighter (Co. Londonderry, Ireland), with a hybrid clasp system. National Museum of Ireland, Dublin

Fig. 24 Gold tore from Clonmacnoise (Co. Offaly, Ireland), a further hybrid clasp. National Museum of Ireland, Dublin

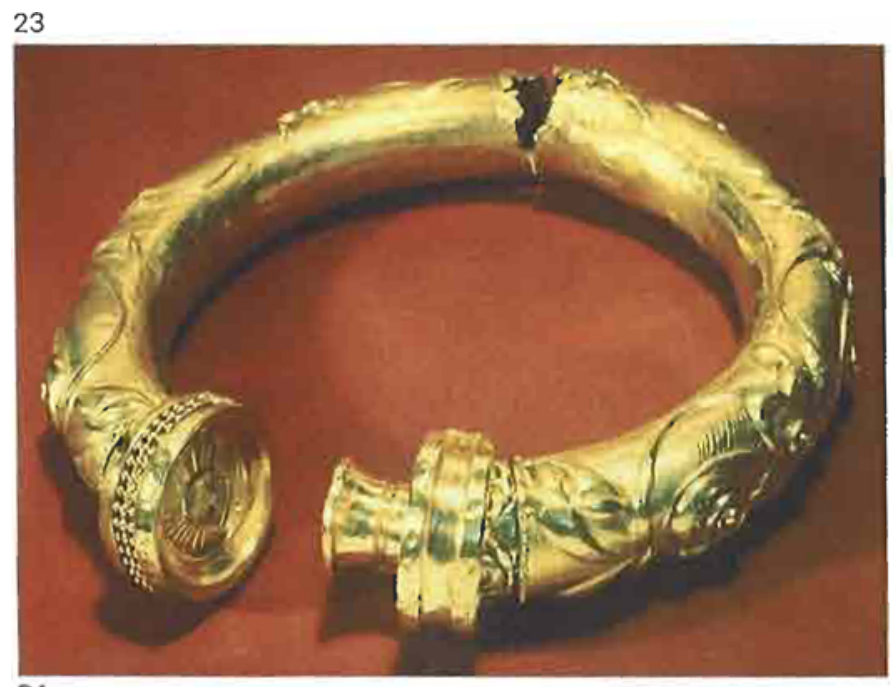

24

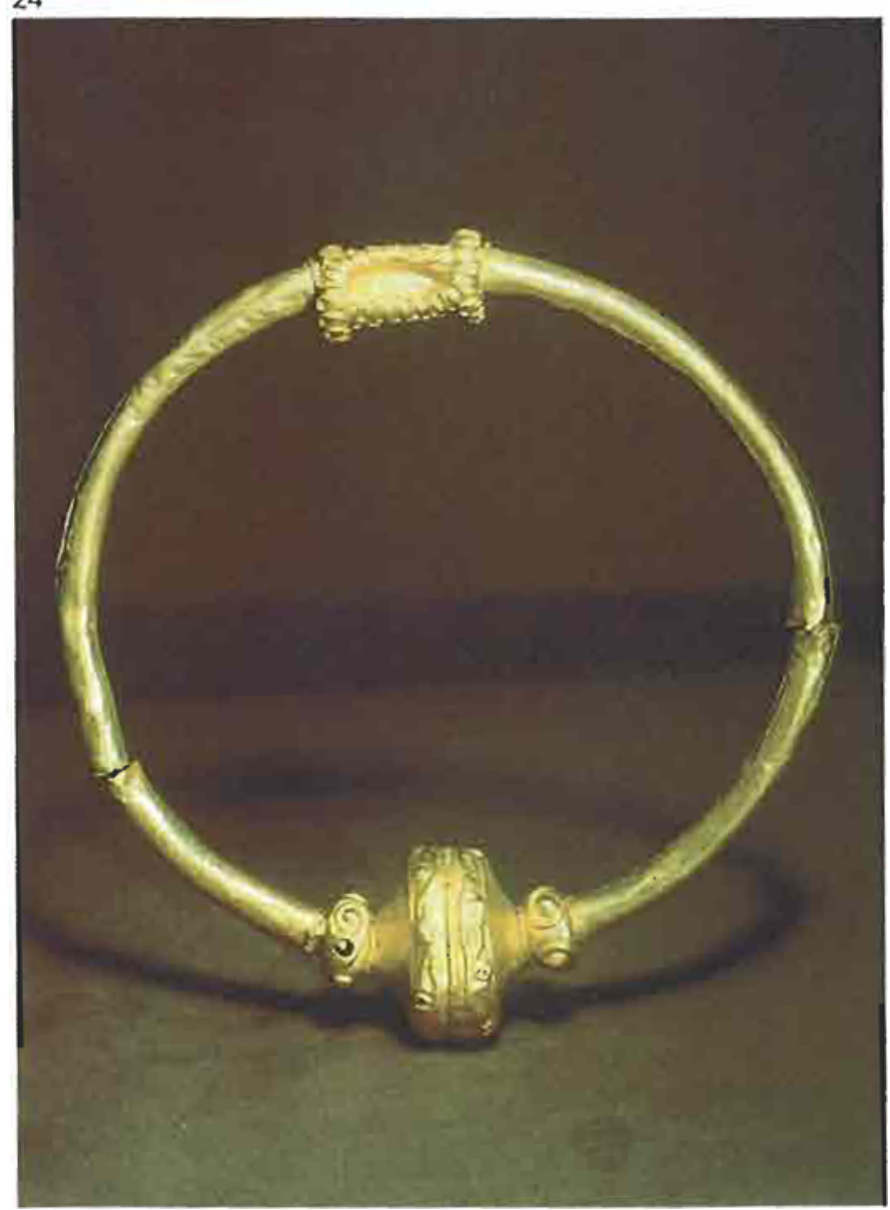




\begin{tabular}{|c|c|c|}
\hline \multicolumn{3}{|c|}{$\begin{array}{c}\text { Table I } \\
\text { Spectrographic Analysis of Torcs from Montans } \\
\text { and Civray (45) }\end{array}$} \\
\hline & Montans & Civray \\
\hline $\mathrm{Cu}$ & 0.07 & 0.442 \\
\hline $\mathrm{Zn}$ & 0.001 & 0.0001 \\
\hline $\mathrm{Pb}$ & 0.0026 & 0.034 \\
\hline Sn & 0.0053 & 0.019 \\
\hline As & 0.003 & 0.011 \\
\hline Sb & 0.002 & 0.004 \\
\hline $\mathrm{Fe}$ & 0.014 & 0.048 \\
\hline$A g$ & 0.597 & 0.710 \\
\hline $\mathrm{NI}$ & 0.001 & 0.004 \\
\hline Bi & 0.0117 & 0.001 \\
\hline co & 0.001 & 0.003 \\
\hline $\mathrm{Hg}$ & 0.001 & 0.021 \\
\hline Si & 0.012 & 0.008 \\
\hline$M n$ & 0.0004 & 0.002 \\
\hline
\end{tabular}

necting them to gold said to have been brought from the sack of Delphi attempted by the Tectosage Celtic tribe in 279 BC (47). In reality, the Delphi-Tectosages source is doubtful: the exploitation of local gold is very likely - as has been noted by Polybius in the 2nd century BC.

For a long time, however, it was claimed that these French neckrings had been imported from southeastern Europe, but, if local gold was used, the converse is also possible, although the Gajic specimen is a rare instance of its type being found outside southwestern France. Unfortunately its composition has not been analysed yet.

The detailed analysis in Table I suggests two arguments for dating these torcs. These are based on the assumption that we are dealing with refined gold, which is fair in the absence of major impurities:

1 Refining is known to have been practised by the Romans, and some of their jewellery is of gold corresponding to the purity required for coinage. If the torcs from southwestern France reflect Roman influence and contact, this dates them to between the end of the 2nd century and the 1st century $\mathrm{BC}$ (the relationship with the Gajic torc then becomes difficult to justify because of historical impossibilities.)

2 If the torcs were made from Macedonian gold staters (which some analyses show were minted from pure refined gold), then there is a basis for supposing that

Fig. 25 Tores with looped terminals, a). Tore from from Snettisham (Norfolk, England); b). detail of a torc from Ipswich (Norfolk) with overmoulded loop. British Museum, London these torcs, such as those from Montans and Civray, were produced before the 2 nd century BC. This is because Macedonian staters were introduced into Gaul as early as the 3rd or 4th century BC. (The Gajic torc could then have been worn by a Gallic warrior during the migrations to southeastern Europe, or, more probably, locally produced under common and contemporary influences, in the early 3rd century BC.)

The hoard of torcs from Fenouillet includes a neckring of 'refined' gold (theoretically containing less than 1 per cent silver) juxtaposed with others of 'natural' pure gold (1 to 2 per cent silver). This situation is paralelled in earliest Celtic gold coinage, where genuine Macedonian staters (in refined gold) were carefully imitated, these locally produced staters being of gold with 1 to 3 per cent silver (48). Comparing the production of tores with that of coins, it is possible to imagine in both cases, which may even be contemporary, the use of imported refined gold (staters?) and semi-refined local gold. The progressive purity of gold used

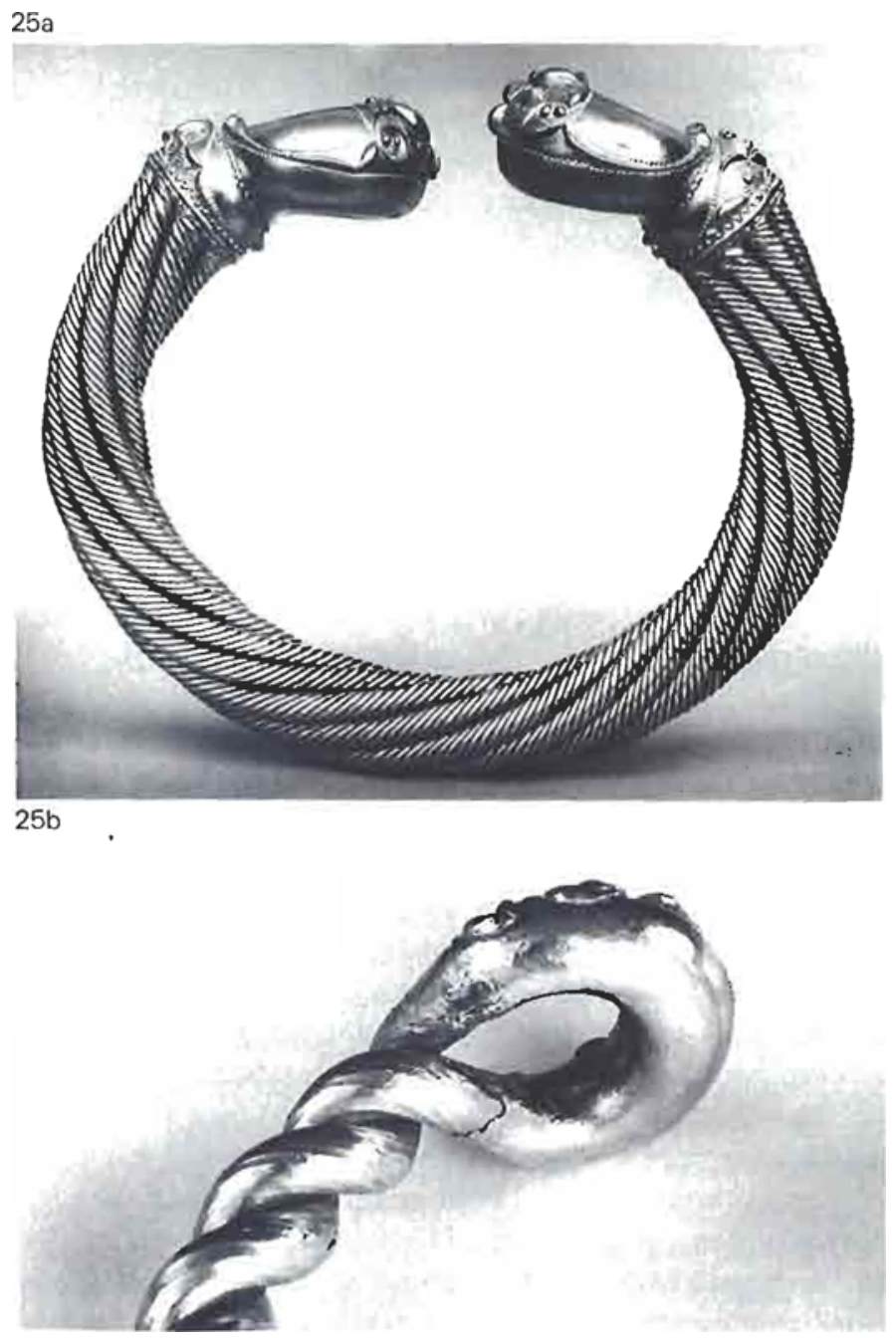


in torcs of the Continental area from the 4th to 1st century $B C$ is a good indication of this process having started early in non-Mediterranean Europe.

It is hoped that the technological approach used in this article for investigating Celtic gold torcs has provided an additional basis for classification and dating, complementing traditional studies of their stylistic and decorative details.

\section{Notes and References}

1 Herodotus, Polybius, Strabo, Diodorus Siculus, Virgil, Livy, Florus..., cf. Daremberg and Saglio, Dictionnaire des Antiquités grecques et romaines 1909, article 'Torques', pp. 375-378; J. De Baye, 'Les torques étaient portées par les hommes chez les Gaulois', Bulletin Monumental, 1886, p. 28

2 W. Holmqvist, Guld Halskragema, Stockholm, 1980

3 C. Eluère, L'Age du Bronze en France: Les Ors Préhistoriques, Picard, Paris, 1982, pp. 158-162; 191,

4 P.V. Glob, The Bog People, London, 1977, pp. 163-166

5 A. Greifenhagen, Schnuckarbeiten in Edelmetalle, Berlin, 1970, p. 1, pl. 29

6 A. Haffner Die westliche Hunsrück Eifel Kultur, Berlin, 1976, pl. 13

7 J.V.S. Megaw, Art of the European Iron Age, 1970, No. 56; P. Jacobstahl, Early Celtic Art, Oxford, 1944, No. 41, 42

8 A. Furger Gunti, 'Der Goldfund von St-Louis bei Basel und ähnliche keltische Schatzfunde', Zeitchr. für archäel. Kunst, 1982, 39, fig. 17

9 C. Eluère, 'L'orfèvrerie pré-romaine au Musée de Cluny', Revue du Louvre, April 1986, p. 2, fig. 17

10 R. Joffroy, Vix et ses trésors, Paris, 1979, pl. XIII-XV

11 F. Lopez Cuevillas, 'Os torques do noroeste Hispanico', Arquivos do Seminario de Estudos Galegos VI, 1932;

F. Lopez Cuevillas, Las Joyas Castrenas, Madrid, 1951, pp. 20-57; B. Pcrex Outeirino, 'Torques', in Gran Encyclopaedia Gallega, XXIX, 1986, pp. 107-110

12 J. Saavedra Machado, 'Torques de oro de Vilas Boas de Tras o Montes', Archivo Espanol de Arqueologia, 1965, p. 75, pl. 2

13 K. Raddatz, Die Schatzfunde der iberischen Halbinsel, Deutsches Archäologisches Institut, Madrid, 1969, pl. 41

14 Analyses of gold mentioned here have been published by A. Hartmann, Prähistorische Goldfunde Europas, S.A.M., Berlin, 1970 and 1982, unless otherwise indicated

15 M. Almagro, 'De orfebreria celtica; el deposit de Berzocona y un brazalete del museo arqueologico nacional', Trabajos de Prehistoria XXVI, 1969, 275-287, pl VI

16 R. Parreira and C. Vaz Pinto, Tesouros da arqueologia portuguesa, Lisbon, 1980, N. 65

17 J. Maluquer De Motes, 'La orfevreria pre romana en la Peninsula Iberica', Pyrenae, 6, 1970, pl. IV \& VI

18 P. Jacobstahl, Early Celtic Ant, Oxford, 1944, pp 47-48

19 P. Jacobstahl, op. cit., No. 44

20 id., No. 45

21 Original in the Museum of Vannes in Brittany, observations made on the electrotype at the Museum of St-Germain

22 J. Keller, 'Das Fürstengrab von Reinheim, Saarland', Germania, 1955, 33-42

23 Acknowledgement is madc to Dr. Schaaff, Director of the Römisch
Gcrmanisches Zentralmuseum in Mainz, Germany, for this document.

24 M. Petrescu Dimbovita and D Marin, 'Le trésor de Baiceni (dép. de Jassy)', Dacia, XIX, 1975, figs. 5-6

25 For example: torc of Kul Oba and Karagodevashkh Kurgens, cf, Catalogue of the exhibition From the Land of the Scythians, New York and Los Angeles

26 P. Jacobstahl, op. cit., No. 43

27 M. Szabo, Sur les traces des Celles en Hongrie, Hereditas, Corvina, 1971, fig. 18

28 J. Maluquer De Motes, op, cit., pl. V

29 C.F.C. Hawkes, 'The Sintra Gold Collar', The British Museum Quarterly, 1971, pp. 38-50

30 I wish to thank the British Museum Research Laboratory, and particularly Dr. Lang, for performing the analyses. See also M. Le Goffic, C. Eluère and A.R. Duval 'Le site de l'âge du Fer et les perles en or de Tréglonou (Finistère)', Bull. Soc. Préhis. Française 1986, pp. 510-533, fig. 25

31 R. Wyss, 'Der Schatzfund von Erstfeld, Frühkeltischer Goldschmuck aus den Zentralalpen', Archaeologische Forschungen, 1975

32 J.P. Mohen, 'La présence celtique de La Tène dans le Sud-Ouest de l'Europe: indices archèologiques', Les mouvements celtiques du Ve au ler siècle avant notre ère, colloquium, Paris, CNRS, 1979, pp. 29-48, fig.11

33 H.E. Joachim, 'Ein bedeutender urgeschichtlicher Fund aus dem Hambacher Forst', Das Rheinische Landesmuseum Bonn, Sonderheft, 1979, pp. 56-59

34 C. Eluère, 1986, op. cit.,

35 A. Duval, C. Eluère and A.R. Duval, et al., 'Le torque gaulois en or de Civray-la-Forêt (Indre-et-Loire)', Revue du Louvre, in press

36 C. Eluère, 'Goldwork of the Iron Age in Barbarian Europe', Gold Bulletin, 1985, 4, 144-155, Fig. 14

37 E. Nylen, 'Le collier d'or de Havor', in catalogue L'or des Vikings, Bordeaux, 1969

38 S. Müller, 'Un collier d'or étranger de l'époque pré-romaine', Mém. de la Soc, royale des Antiq. du Nord, Copenhague, 1900-1901 pp 347-351

39 A. Furger Gunti, op. cit., No. 62

40 R. Joffroy, 'Le torque de Mailly-le-Camp (Aube)', Monuments et Mémoires Piot, 56, 1969; C. Eluère, 'Goldringe mit Eisenkern den Spätlatenerzeit', Fundberichue aus Baden-Würtemberg, 1987 (in press)

41 P. Jacobstahl, op. cit., No. 62

42 Catalogue Treasures of Early Irish Art, Metropolitan Museum, New York, Nos, 21 and 14 (for Clonmacnoise, description from catalogue)

43 J. Brailsford, J.E. Stapley, 'The Ipswich tores', Proc, of the Prehist. Society, 1972, 219-234, pl. XXI-XXXVI

E. Owles, 'The Ipswich gold torcs', Antiquity, 1969, XLIII, 208-212 pl. XXX-XXXI

44 C. Eluère, 1985, op. cit., Fig. 1

45 Spectrographical analyses were carried out in the Laboratoire de Recherche des Musées de France (L.R.M.F.), Louvre, which I thank here again.

46 Samples kindly provided by Mr. Genouillac and analysed by S.E.M. by A.R. Duval in the L.R.M.F. I thank them both for their help.

47 M. Labrousse, Toulouse Antique, 1968, pp 109-111, 129-136

48 A. Hartmann, 'Über Materialanalysen an Goldmünzen der keltischen Bojor', Jahrbuch des R.G.Z.M., Mainz, 1985, pp 660-674 